August $2003 \quad$ - NREL/SR-710-34646

\title{
Sri Lanka Wind Farm Analysis and Site Selection Assistance
}

\author{
M. Young and R. Vilhauer \\ Global Energy Concepts, LLC \\ Kirkland, Washington
}

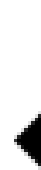

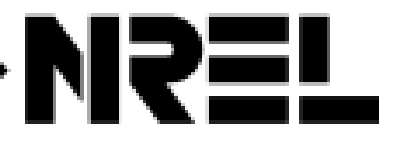

National Renewable Energy Laboratory

1617 Cole Boulevard

Golden, Colorado 80401-3393

NREL is a U.S. Department of Energy Laboratory

Operated by Midwest Research Institute $\bullet$ Battelle $\bullet$ Bechtel

Contract No. DE-AC36-99-G010337 


\section{Sri Lanka Wind Farm Analysis and Site Selection Assistance}

M. Young and R. Vilhauer Global Energy Concepts, LLC Kirkland, Washington

NREL Technical Monitor: I. Baring-Gould

Prepared under Subcontract No. ACX-3-33455-01

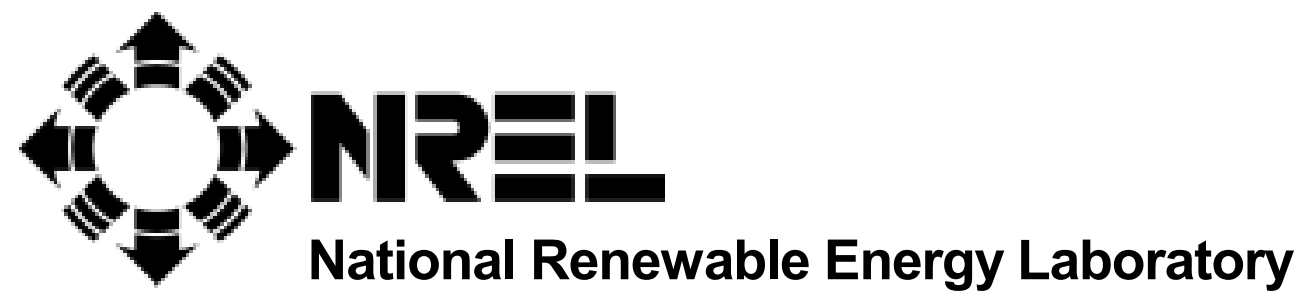

1617 Cole Boulevard

Golden, Colorado 80401-3393

NREL is a U.S. Department of Energy Laboratory

Operated by Midwest Research Institute • Battelle • Bechtel

Contract No. DE-AC36-99-G010337 


\section{NOTICE}

This report was prepared as an account of work sponsored by an agency of the United States government. Neither the United States government nor any agency thereof, nor any of their employees, makes any warranty, express or implied, or assumes any legal liability or responsibility for the accuracy, completeness, or usefulness of any information, apparatus, product, or process disclosed, or represents that its use would not infringe privately owned rights. Reference herein to any specific commercial product, process, or service by trade name, trademark, manufacturer, or otherwise does not necessarily constitute or imply its endorsement, recommendation, or favoring by the United States government or any agency thereof. The views and opinions of authors expressed herein do not necessarily state or reflect those of the United States government or any agency thereof.

Available electronically at http://www.osti.gov/bridge

Available for a processing fee to U.S. Department of Energy and its contractors, in paper, from:

U.S. Department of Energy

Office of Scientific and Technical Information

P.O. Box 62

Oak Ridge, TN 37831-0062

phone: 865.576 .8401

fax: 865.576.5728

email: reports@adonis.osti.gov

Available for sale to the public, in paper, from:

U.S. Department of Commerce

National Technical Information Service

5285 Port Royal Road

Springfield, VA 22161

phone: 800.553.6847

fax: 703.605.6900

email: orders@ntis.fedworld.gov

online ordering: http://www.ntis.gov/ordering.htm 


\section{Executive Summary}

The United States Department of Energy (DOE), through the National Renewable Energy Laboratory (NREL), has been working in partnership with the U.S. Agency for International Development (USAID) in an on-going process to quantify the Sri Lanka wind energy potential and foster wind energy development. Work to date includes completion of the NREL wind atlas for Sri Lanka. In addition, the Ceylon Electricity Board (CEB) has conducted a wind resource assessment of several areas of the country and has successfully completed and is currently operating a 3-MW pilot wind project. A review of the work completed to date indicates that additional activities are necessary to provide Sri Lanka with the tools necessary to identify the best wind energy development opportunities. In addition, there is a need to identify key policy, regulatory, business and infrastructure issues that affect wind energy development and to recommend steps to encourage and support wind power development and investment.

To meet these needs, NREL retained Global Energy Concepts, LLC (GEC) to identify key market barriers, develop a site screening process applicable for Sri Lanka, apply the process to the most favorable areas for wind resource potential as identified by the NREL wind atlas, and provide recommendations on pre-development activities for near-term wind project development for the most promising sites. GEC worked closely with CEB in completing this work. At the suggestion of NREL and USAID personnel, the work was focused on the southern coast, west coast, and central portion of Sri Lanka with a limited review of the north coast. Due to the ongoing civil conflict, the northern and eastern regions of the country were not considered for any near-term development opportunities. The following areas were identified and evaluated with respect to the screening criteria:

- Southeast Coast - Hambantota to Buthawa

- West Coast - Kalpitiya Peninsula

- Northwest Coast - Mannar Island

- North Coast - Jaffna District

- Central Province - Ambewela area

Sri Lanka has considerable available land with wind resource potential sufficient for development; however, the near-term potential wind power capacity expansion is limited by the electricity transmission infrastructure. CEB estimates the grid cannot accommodate additional wind capacity more than $7 \%$ of the peak load, or approximately $100 \mathrm{MW}$. In addition, CEB estimates that installing more than $20 \mathrm{MW}$ of wind capacity in any given region may adversely impact local grid stability and power quality. To further identify and overcome these limits, improvements to the infrastructure along with grid-impact studies should be conducted.

The intra-annual nature of the wind resource in Sri Lanka is not optimally matched to the seasonal variations in hydro-electric generation. The maximum winds occur during the wettest periods so wind power cannot be expected to significantly help mitigate capacity constraints in the dry seasons. 
A Request for Proposal (RFP) for a 20-MW wind farm to be bid on a build, own and operate (BOO) basis was recently issued by CEB. Only one bidder was willing or able to submit a bid. At least one prospective bidder has complained to the Energy Supply Committee about the qualification requirements and tariff calculation method required by the RFP. The RFP process may require modification in order to ensure it does not inadvertently include barriers to wind project development.

The review of government policies indicated that while there is a tax waiver and some level of tax holidays related to all development projects, there are currently no policy incentives specific to renewable energy development. Adopting policies that offer financial incentives to develop wind power is a historically effective way to foster further wind power development. If the current power shortage continues, adopting these policies may prove to be a useful tool to increase capacity quickly since wind power projects are typically developed faster than thermal projects.

Sri Lanka's $7 \%$ to $8 \%$ annual load growth that exceeds generation expansion, its heavy reliance on hydro power, with fluctuating capacity depending on drought conditions, and its limited additional hydro development potential combined with pressure to decrease electricity tariffs has motivated CEB and the government to pursue additional and more cost-effective generation technology. This includes fuel-oil and diesel-fired thermal power generation expansion in the near term and large coal-fired thermal generation expansion in the next decade.

The current avoided cost for electricity generation in Sri Lanka is approximately $\$ 0.06 / \mathrm{kWh}$. These costs are expensive compared to other countries in the region due to the reliance on imported equipment and fuel along with unfavorable exchange rates. The avoided cost for electricity generation is expected to remain high for at least the next decade when a significant portion of the country's generation capacity is planned to be shifted to coal-fired generation.

Progress on electrifying rural communities in Sri Lanka is being made primarily through grid extension. Most non-electrified communities are relatively close to the existing grid and thus grid extension has proven less expensive than installing remote off-grid systems for electrification. CEB currently has no plans to pursue the installation of these systems.

There are several locations in Sri Lanka that show near-term potential for cost-effective utilityscale wind power development given the current economic climate and infrastructure status in Sri Lanka. The most promising sites identified, in order of potential feasibility, are the Kalpitiya Peninsula, the National Livestock Board cattle farm near Ambewela and the southeast coastal areas from Hambantota to Buthawa. Several other locations such as Mannar Island and the Jaffna District have favorable wind resource potential; however, the infrastructure and other issues pose significant barriers to near-term development.

During the performance of this contract, GEC visited the cattle farm site near Ambewela, but did not visit either Kalpitiya or the southeast coast sites. However, GEC personnel visited the southeast coast while performing work for CEB during 1996 and this is the location of CEB's 3-MW pilot wind project. Wind resource assessment activities have been conducted on all three 
sites. These data were reviewed along with information obtained from CEB and other sources to carry out the work under this contract.

The Kalpitiya Peninsula and the Hambantota area on the southeast coast were identified as possible locations for a $20-\mathrm{MW}$ wind power project in a wind-only RFP recently released by CEB. The bidders are responsible for choosing the exact location for the project. At the time of writing, a winning bidder has not been identified; however, the CEB expects most or all projects to be proposed for the Kalpitiya area.

The Ambewela site and the Kalpitiya Peninsula have similar wind resource potential, Class 5. The Kalpitiya area would require interconnection upgrades in order to accommodate capacity beyond the 20-MW wind project already under consideration and yet slightly outranks development of the Ambewela site due to better access and less complex terrain. Although the southeast coast has a lower wind resource ranking than the Kalpitiya and Ambewela sites, it has a higher ranking than other Class 4 wind resource potential areas due to grid interconnection potential, site accessibility, and community acceptance. Cost of energy (COE) values were estimated for each site. The COE for the Kalpitiya and Ambewela sites are estimated to be less than the avoided cost of energy in Sri Lanka, which is approximately $\$ 0.06 / \mathrm{kWh}$. A project on the southeast coast may not be economical if the basis for determining economic viability is the avoided cost of approximately $\$ 0.06$ per $\mathrm{kWh}$.

NREL's wind atlas is a good starting point for locating areas and assisting in the assessment of wind energy potential. In addition, CEB has conducted limited wind resource assessment at three of the five areas that were ranked for development potential. Although initial ranking of a site is a useful indicator of development potential, on-site wind speed measurements at turbine hub height will be required prior to any development activities.

A disciplined review of the NREL wind atlas, the Sri Lankan highway restrictions and capacities and the site evaluation methodology developed herein should be applied to other areas of Sri Lanka to identify additional areas with wind energy development potential. In addition, a system-wide study should be conducted to identify the effects of additional wind power capacity on the grid in the most likely areas for development.

Providing CEB with additional analysis tools and an increased understanding of developers' needs for the successful financing and construction of a wind project will also promote future wind power development. Expanding the number of in-country organizations that understand the issues critical to project development and how they impact site selection will facilitate further development of wind energy in Sri Lanka. 


\section{Table of Contents}

1 Introduction ................................................................................................................................ 1

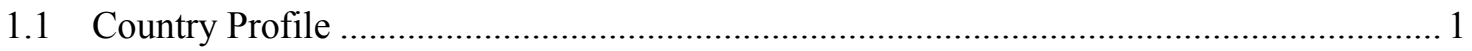

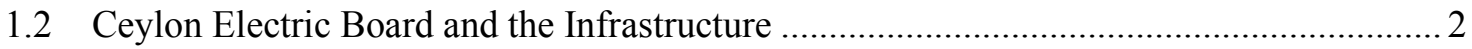

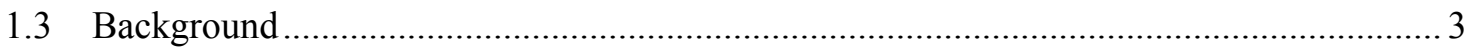

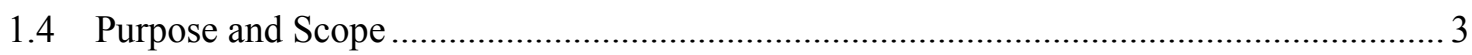

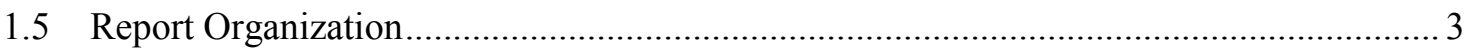

2 Identification of National Wind Energy Production Potential .......................................... 4

3 Assessment of Key Market Barriers........................................................................................6

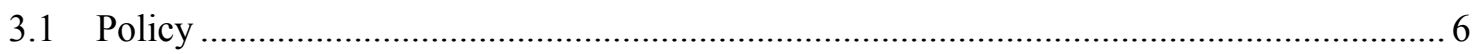

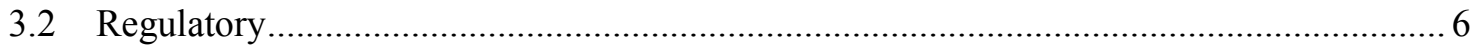

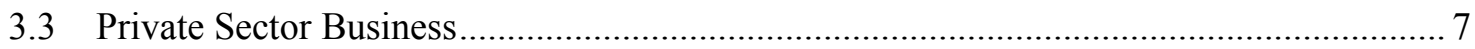

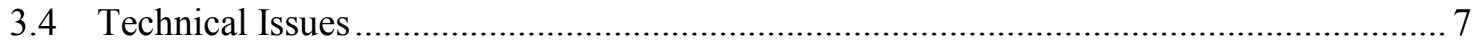

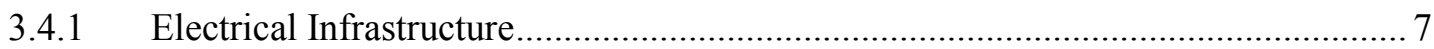

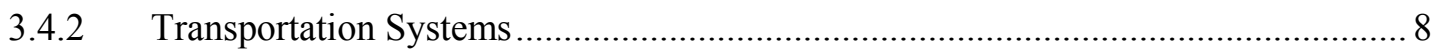

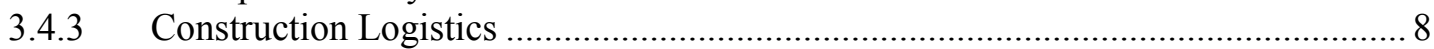

3.4.4 Intra-Annual Variation in Wind Resource ..................................................... 8

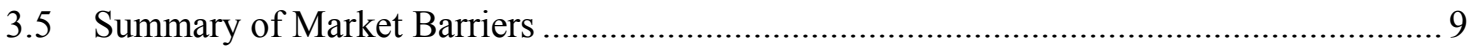

$4 \quad$ Site Screening Process................................................................................................................... 10

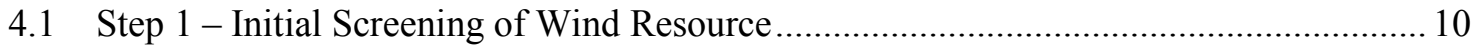

4.2 Step 2 - Initial Screening for Land Suitability .......................................................... 11

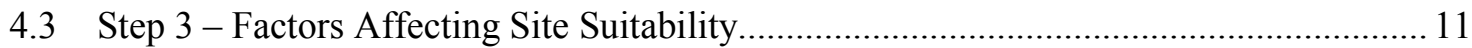

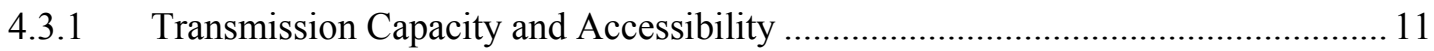

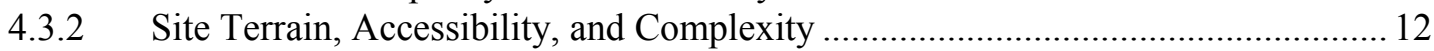

4.3.3 Terrain Orientation to Prevailing Wind .................................................................... 12

4.3.4 Nearby Resident's Concerns and Social Acceptability of

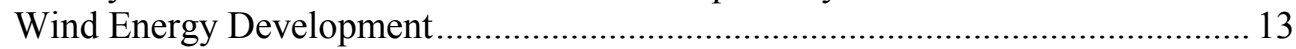

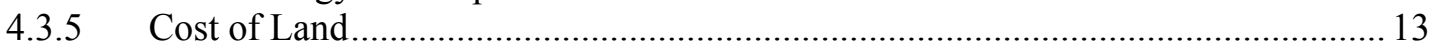

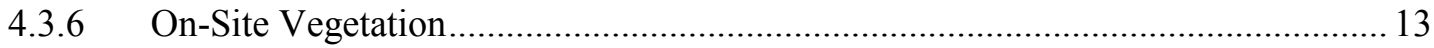

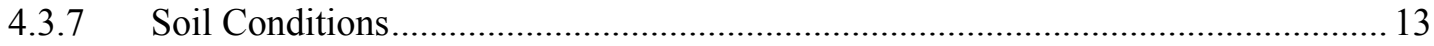

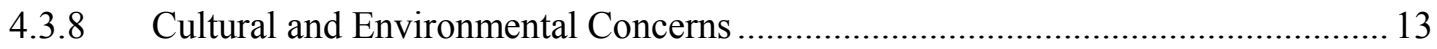

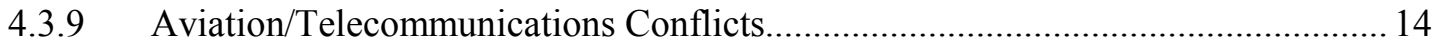

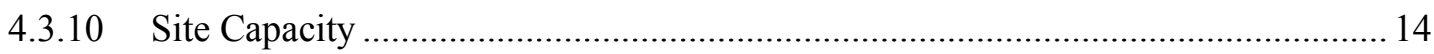

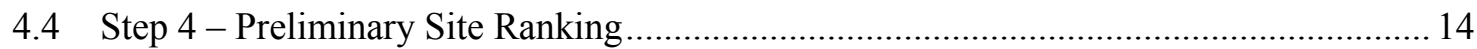

4.5 Step 5 - Quantitative Site Assessment................................................................... 15

$5 \quad$ Initial Screening of Potential Wind Power Generation Sites .......................................... 17

5.1 Southeast Coast - Hambantota to Buthawa ................................................................... 17

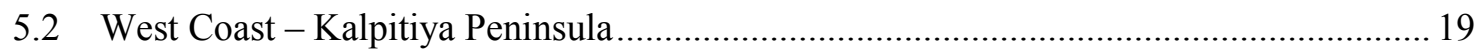

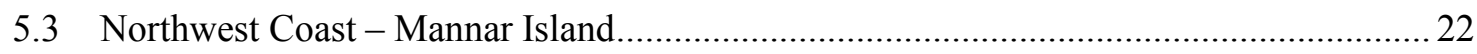

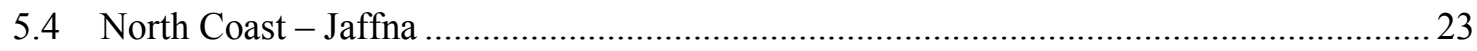

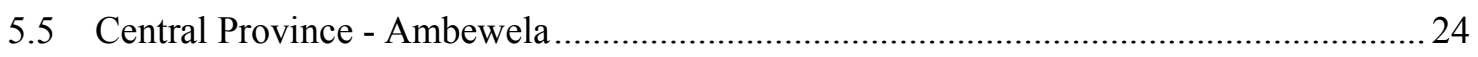


6 Conclusions and Recommendations for Near-term Wind Power Development ........... 29

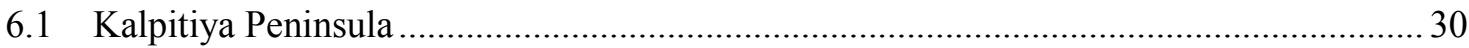

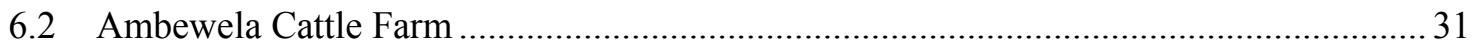

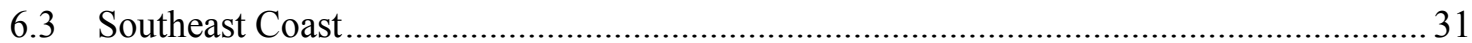

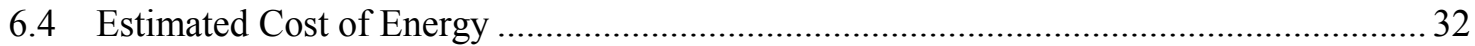

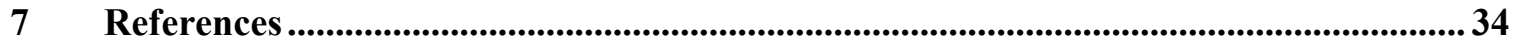




\section{List of Figures}

Figure 5-1. Southeast Coast Area ................................................................................... 18

Figure 5-2. Kalpitiya Peninsula and Puttalam Area............................................................ 20

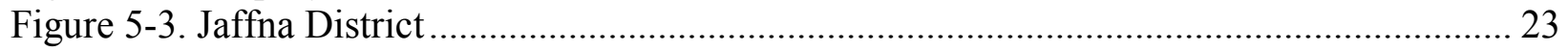

Figure 5-4. Ambewela Cattle Farm Location ...................................................................... 25

Figure 5-5. Ambewela Cattle Farm Meteorological Site - Southwest View ............................ 26

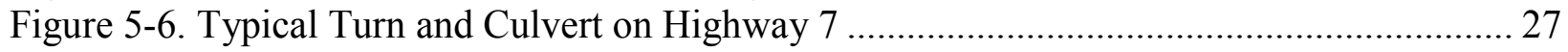

\section{List of Tables}

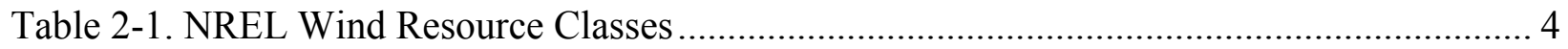

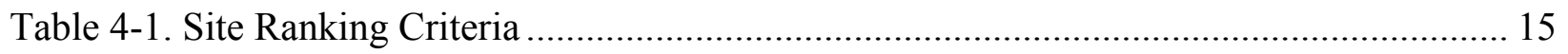

Table 5-1. Southeast Coast Site Evaluation Results ............................................................... 19

Table 5-2. Kalpitiya Peninsula Site Evaluation Results ................................................. 21

Table 5-3. Mannar Island Site Evaluation Results............................................................ 22

Table 5-4. Jaffna Site Evaluation Results ............................................................................. 24

Table 5-5. Ambewela Cattle Farm Site Evaluation Results .................................................... 28

Table 6-1. Cumulative Site Evaluation Scores ..................................................................... 30

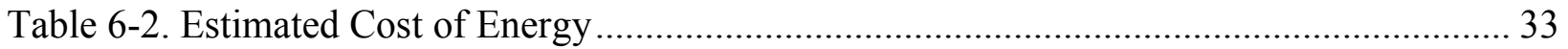




\section{Introduction}

The United States Department of Energy (DOE), through the National Renewable Energy Laboratory (NREL), has been working in partnership with the U.S. Agency for International Development (USAID) in an on-going process to quantify the Sri Lanka wind energy potential and foster wind energy development. Work to date includes completion of the NREL wind atlas for Sri Lanka. In addition, the Ceylon Electricity Board (CEB) has conducted wind resource assessment of several areas of the country and has successfully completed and is currently operating a 3-MW pilot wind project. A review of the work completed to date indicates that additional activities are necessary to provide Sri Lanka with the tools necessary to identify the best wind energy development opportunities. In addition, there is a need to identify key policy, regulatory, business and infrastructure issues that affect wind energy development and to recommend steps to encourage and support wind power development and investment.

To meet these needs, NREL retained Global Energy Concepts, LLC (GEC) to identify key market barriers, develop a site screening process applicable for Sri Lanka, apply the process to the most favorable areas for wind resource potential as identified by the NREL wind atlas, and provide recommendations on pre-development activities for near-term wind project development for the most promising sites. GEC worked closely with CEB in completing this work. At the suggestion of NREL and USAID personnel, the work was focused on the southern coast, west coast, and central portion of Sri Lanka with a limited review of the north coast. Due to the ongoing civil conflict, the northern and eastern regions of the country were not considered for any near-term development opportunities. The following areas were identified and evaluated with respect to the screening criteria:

- Southeast Coast - Hambantota to Buthawa

- West Coast - Kalpitiya Peninsula

- Northwest Coast - Mannar Island

- North Coast - Jaffna District

- Central Province - Ambewela are

\subsection{Country Profile}

The Democratic Socialist Republic of Sri Lanka (formerly Ceylon) is an island country located off the southern tip of India with an area of approximately 25,000 square miles and a population of over 18 million. Colombo, on the central west coast is the capital and largest city with a population of over 2 million. Due to political unrest, some northern and eastern regions of the country are restricted to travel. Although there have been some indications of potential resolution in this political struggle, project development of any type is not currently feasible in the affected regions.

Beyond the coastal plains, the central mountain massif dominates Sri Lanka's topography, with the highest point at Pidurutalagala $(2,524 \mathrm{~m})$. The coastal plains are broader in the north, tapering off in the long low-lying Jaffna peninsula. Several fast-flowing non-navigable rivers arise in the mountains including longest, the Mahaweli Ganga, which is $322 \mathrm{~km}$. 
The lowlands are always hot, particularly from March to May. The highlands have a cooler climate. The southwest monsoon season is from mid-May to September, the northeast monsoon season from November to March, and the dry season from March to mid-May. Sri Lanka is mainly an agricultural country. Although rice is Sri Lanka's largest crop, tea, coconut, and rubber are the main economic agricultural crops. Approximately $29 \%$ of the land is used for agriculture and about $22 \%$ is forested. Sri Lanka is well known for its nature reserves which cover approximately $10 \%$ of the island. These reserves provide protection for numerous species, including elephants and leopards. However, reduction of the natural tropical hardwood forest has endangered several animal species.

\subsection{Ceylon Electric Board and the Infrastructure}

CEB was established by the Government of Sri Lanka and is currently responsible for the generation, transmission, supply, distribution, and sale of electrical energy in Sri Lanka. CEB is in the process of reorganization and effective in October 2003 will be operating as several individual companies. Reorganization will be based on the specific activities of CEB. For example, one company will be responsible for generation, another company for transmission services, another for electricity distribution, and so on. For the time being, the government will still own the newly formed companies.

As of 2000, CEB had 1,700 MW of installed capacity with a peak load of 1,440 MW. Approximately 1,135 MW is large run-of-river hydro projects and the remaining capacity is thermal generation including about $137 \mathrm{MW}$ of thermal capacity owned and operated by independent power producers (IPPs) under contract with CEB. CEB owns a 3-MW pilot wind power project. In addition to this CEB-controlled capacity, there is an estimated $210 \mathrm{MW}$ of small (less than $10 \mathrm{MW}$ ) non-dispatchable hydro plants installed throughout the country. There is also an unknown number of small remote unregulated village power systems consisting of mostly diesel with some solar and wind generation.

The total exploitable hydropower potential of Sri Lanka is estimated to be about $2000 \mathrm{MW}$. Only a few large hydro projects totaling $220 \mathrm{MW}$ are planned in the near-term which reflects the difficulties of finding cost-effective sites suitable for development. Additional thermal generation is under construction or being planned for the near future, including a $212 \mathrm{MW}$ thermal power plant scheduled for completion by the end of 2003. This thermal plant will be built, owned, and operated by an IPP. In 2000, IPPs supplied over $14 \%$ of the annual electricity requirement for Sri Lanka.

CEB operates a $220 \mathrm{kV} / 132 \mathrm{kV}$ transmission network with a total length of approximately 1,600 $\mathrm{km}$. Although physical line capacity is adequate for additional capacity in most areas, system stability and current substation capacity preclude additional capacity in many areas. Capacity constraints of specific areas is discussed further later in the report.

As of 2001, approximately $70 \%$ of the country's electricity demand was met by the hydro power plants in normal rainfall years. However, with limited hydropower expansion opportunities, the $7 \%-8 \%$ annual electricity growth is expected to be provided by thermal power plants. Sensitivity to the adverse effects of conventional energy generation on the global climate has prompted CEB to support long-term wind energy development for utility-scale electricity generation $[4,5]$. 


\subsection{Background}

The completion of the Wind Energy Resource Atlas of Sri Lanka by NREL is a significant step in quantifying the country's wind energy potential. However, considerable additional effort is necessary to fill the gap between knowing the estimated wind resource from the atlas and completing the development of a utility-scale wind energy facility.

From 1988 to 1992, CEB conducted a wind resource assessment study in the southern lowlands that included nine 20-m meteorological towers [2]. In 1998, the national utility, CEB conducted a competitive bid process for the installation of a 3-MW pilot wind project in the south coast region of Sir Lanka. This project was successfully completed in March 1999 and is currently in operation. In 1999, CEB began a second wind resource monitoring program on the west coast in the Puttalam area and in the central regions of Sri Lanka [3].

CEB recently released a Request for Proposal (RFP) for a 20-MW wind project. However, after the bidder qualification process, only one qualified applicant bid a project in response to the RFP. Several concerns have been identified regarding the structure of the RFP and the bidding process that discouraged potential developers from responding to the RFP.

\subsection{Purpose and Scope}

The objective of this work is to identify key market barriers to wind energy development, develop a site screening process applicable for Sri Lanka, apply the process to the most favorable areas for wind resource potential as identified by the NREL wind atlas, and provide recommendations on pre-development activities for near-term wind project development for the most promising sites. To meet these objectives GEC developed a site screening process that could be used to evaluate relatively large areas being considered for utility-scale wind energy development. The application of the process was demonstrated for several sites identified by the NREL wind atlas.

\subsection{Report Organization}

This report is divided into six sections and appendixes. After this introductory section, the wind energy potential of the country is presented in Section 2. The assessment of key market barriers is presented in Section 3. Section 4 provides a description of the site screening process developed for Sri Lanka and Section 5 presents the initial screening of potential wind power generation sites. The results of the application of the screening criteria are also presented in Section 5. Recommendations for near-term development of potential project sites are included as Section 6. Section 6 also identifies areas of interest for further evaluation, makes recommendations concerning meteorological tower installation for additional wind resource monitoring and presents estimated costs of energy for several sites. Appendix A is a Site Visit Summary that briefly describes the activities performed by GEC while in Sri Lanka and identifies various government agencies, companies, and people with whom meetings were held to gain insights into issues unique to Sri Lanka. 


\section{Identification of National Wind Power Potential}

The NREL wind-mapping results for Sri Lanka show many areas that are estimated to have good-to-excellent wind resources [1]. These areas are concentrated largely in two major regions. The first is the northwestern coastal region from the Kalpitiya Peninsula north to Mannar Island and the Jaffna Peninsula. The second region is the central highlands in the interior of the country, largely in the Central Province but also in parts of Sargamuwa and Uva Provinces. Much of the highlands region is over $1500 \mathrm{~m}$ in elevation, and the best sites are those that are well exposed to the strong southwest monsoon winds. Other regions with notable areas of good wind resource include the exposed terrain in the southern part of the North Central Province and coastal areas in the southeastern part of the Southern Province. High-quality wind measurement data were available to confirm the map estimates of wind resource in specific areas, such as the Kalpitiya Peninsula, the central highlands, and the southeast coast. Table 2-1 lists the wind resource classes as used by the NREL wind atlas, their corresponding average wind speeds and wind power densities at 50-m height above ground level (agl).

Table 2-1. NREL Wind Resource Classes

\begin{tabular}{|c|c|c|c|}
\hline Class & $\begin{array}{c}\text { Resource } \\
\text { Potential } \\
\text { (Utility Scale) }\end{array}$ & $\begin{array}{c}\text { Wind Power } \\
\left.\text { Density (W/m }{ }^{2}\right) \\
@ 50 \mathrm{~m} \mathrm{agl}\end{array}$ & $\begin{array}{c}\text { Wind Speed } \\
(\mathrm{m} / \mathrm{s}) \\
@ 50 \mathrm{~m} \text { agl }\end{array}$ \\
\hline 1 & Poor & $0-200$ & $0.0-5.6$ \\
\hline 2 & Marginal & $200-300$ & $5.6-6.4$ \\
\hline 3 & Moderate & $300-400$ & $6.4-7.0$ \\
\hline 4 & Good & $400-500$ & $7.0-7.5$ \\
\hline 5 & Excellent & $500-600$ & $7.5-8.0$ \\
\hline 6 & Excellent & $600-800$ & $8.0-8.8$ \\
\hline 7 & Excellent & $>800$ & $>8.8$ \\
\hline
\end{tabular}

(a) Mean wind speed is estimated assuming a sea level elevation and a Weibull distribution of wind speeds with a shape factor $(k)$ of 2.0. The actual mean wind speed may differ from these estimated values by as much as 20 percent, depending on the actual wind speed distribution (or Weibull $\mathrm{k}$ value) and elevation above sea level.

NREL estimates that there are nearly $5000 \mathrm{~km}^{2}$ of windy areas with good-to-excellent wind resource potential in Sri Lanka after accounting for excluded lands such as national parks and reserves and archaeological and cultural sites. About $4100 \mathrm{~km}^{2}$ of the total windy area is land and about $700 \mathrm{~km}^{2}$ is lagoon. The windy land represents about $6 \%$ of the total land area $\left(65,600 \mathrm{~km}^{2}\right)$ of Sri Lanka. Using a conservative assumption of $5 \mathrm{MW}$ per $\mathrm{km}^{2}$, this windy land could support almost 20,000 MW of potential installed capacity. If the windy lagoons are included, the total wind potential increases to approximately $24,000 \mathrm{MW}$. If areas with moderate wind resource potential are considered, the estimated total windy land area increases to approximately $10,000 \mathrm{~km}^{2}$, or almost $15 \%$ of the total land area of Sri Lanka. This amount of windy land could support more than 50,000 MW of installed capacity.

However, there are many other factors that limit the potential installed wind generation capacity in Sri Lanka such as grid capacity. Sri Lanka has considerable available land with wind resource potential sufficient for development; however, the near-term potential wind power capacity expansion is limited by the electricity transmission infrastructure. CEB estimates the grid cannot accommodate wind capacity more than $7 \%$ of the peak load, or approximately $100 \mathrm{MW}$. In 
addition, CEB estimates that installing more than $20 \mathrm{MW}$ of wind capacity in any given region may adversely impact local grid stability and power quality. To further define and overcome these limits, improvements to the infrastructure along with grid-impact studies should be conducted. An accurate figure for the near-term technically feasible potential wind power capacity can only be reached after detailed grid-impact studies. However, it is expected that a total wind power capacity greater than $15 \%$ of the peak load $(215 \mathrm{MW})$ would be difficult to achieve without major upgrades to the transmission and generation infrastructure. 


\section{Assessment of Key Market Barriers}

Wind energy development is not only affected by technical issues but also by the regulatory, political, and economic environment. Because CEB is owned by the government and is ultimately responsible for all of the electricity generation in Sri Lanka, there is a close relationship between the regulatory, business, and political issues impacting wind energy development. To assess the key issues that impact wind energy development, GEC met with many stakeholders including people from several divisions of CEB, the Energy Supply Committee, the Bureau of Infrastructure Investment, a wind energy consultant, and a representative of a private investment company. A Site Visit Summary, included as Appendix A, provides a brief summary of these meetings and other GEC activities during our in-country visit.

In addition to the useful information and documents that were gathered, the opportunity to meet with stakeholders from a variety of perspectives was quite beneficial. In late 2002, CEB release a Request for Proposals (RFP) for $20 \mathrm{MW}$ of wind generation [6]. The intended structure of the project is build, own and operate (BOO) where CEB will purchase the output from the project through a long-term power purchase agreement (PPA). Although CEB had previously considered owning and operating wind generation, they have changed their strategy towards a BOO approach for wind as well as other types of generation.

Key market drivers or barriers can be divided into several categories including policy, regulatory, business, and infrastructure. Some of the issues addressed by GEC in their research include the pricing of electricity, competing supply options, incentives for renewable electricity generation, current environment for independent power producers (IPP), utility experience with PPAs and deregulation. Our research indicates that several of these factors currently have a negative impact on the potential development of wind energy projects in Sri Lanka. Following is a discussion of each of these categories and a summary of recommended changes that may foster wind energy development in the future.

\subsection{Policy}

The Government of Sri Lanka has enacted several policies to encourage foreign investment and infrastructure development. There is currently a waiver on import taxes for equipment and foreign investors can obtain a reasonable level of revenue tax holidays. There are, however, no specific incentives for the development or operation of renewable energy projects.

\subsection{Regulatory}

The Government of Sri Lanka's stated goal for future electricity generation is to use the leastcost source. CEB supports using renewable electricity as a part of the generation mix, as evidenced by their investment in wind resource assessment. However, because they are inexperienced with wind generation, they are not likely to extensively promote wind energy development unless it is clearly a least-cost solution. Given other infrastructure barriers, which are discussed below, wind energy incentives or regulatory actions may be required to foster significant wind power development. 


\subsection{Private Sector Business}

CEB controls all of the electricity generation, traditionally through the ownership and operation of power projects and more recently by purchasing power. There are now several conventional energy projects that have been successfully developed by IPPs under CEB solicitations. These arrangements have proven mutually beneficial to CEB and the private sector and were used, at least partially, as a model for the recent wind RFP process.

There were some aspects of the recent RFP for $20 \mathrm{MW}$ of wind that deterred private investors from bidding on the project. When the RFP was released, 14 organizations expressed interest but only one of the bidders was able or willing to submit a bid. At least one of the prospective bidders was unable to meet the requirement that the bidder or a partner must have successfully developed a wind project with a total cost of at least $\$ 10$ million and maintain at least a $10 \%$ equity stake in the project for five years. This requirement may have impaired Sri Lankan firms that are inexperienced in wind power project development to bid on the project.

The same bidder also objected to the tariff calculation requirements required by the RFP. The tariff was required to be calculated as the sum of a scalable rupee component, non-scalable rupee component and a non-scalable U.S. dollar component. The scalable rupee component was not allowed to exceed $40 \%$ of the total rupee component (sum of the scalable and non-scalable components). The bidder expected to be able to propose a lower tariff if it were not for this requirement.

A formal complaint related to the qualification conditions and cost calculation methods required by the RFP has been filed by a private Sri Lankan investment company and the wind power project RFP process is being reviewed by the Energy Supply Committee.

\subsection{Technical Issues}

There are several technical issues that result in challenges, if not barriers, to the development of wind energy in Sri Lanka. These technical issues are further categorized and discussed below.

\subsubsection{Electrical Infrastructure}

In most areas of the country, the transmission lines have adequate capacity to accommodate additional power from moderate sized generation projects including wind. The exception is in northern Sri Lanka where much of the electrical infrastructure has been damaged. Unfortunately, the overall system stability and the substation capacity preclude the addition of any substantial amounts of capacity in many areas. On the west coast and in the southern region most substations could accommodate only about $20 \mathrm{MW}$ of additional capacity. Substation capacity in the central hills can accommodate somewhat larger amounts of additional capacity, perhaps up as much as 30-50 MW. Detailed grid-impact studies may conclude that larger projects can be installed with minimal impact in some areas.

GEC met with several divisions of CEB that expressed a need for better analytical tools and training for determining the limitations of the electrical infrastructure and the potential impact of wind on their system. CEB expressed their concern in adding any large non-dispatchable energy generation in light of the more than $200 \mathrm{MW}$ of independently operated small hydro systems. Commercial customers already complain of significant fluctuations in voltage and frequency. 
With additional analysis tools and expertise CEB could gain a better understanding of where the strengths and weaknesses exist in the system. Without these tools, CEB's only choice is to be conservative in adding capacity to the system, particularly non-dispatchable and variable generation such as wind power. CEB's current estimate is that the system is limited to an additional wind capacity of $7 \%$ of peak load, or approximately $100 \mathrm{MW}$.

\subsubsection{Transportation Systems}

Colombo has a modern, medium-size container port that is adequate for receiving large utilityscale wind equipment. There are several smaller ports along the west and south coasts where equipment could be shipped by barge. In some cases this is likely to be more logistically feasible than transporting equipment by truck for long distances.

The Road Development Authority in Sri Lanka is likely to have specific weight and dimensions limitations for the major roads. GEC has not yet been able to obtain a contact for this organization. However, as discussed in the Site Screening section of this report, the roads tend to be relatively narrow and underdeveloped.

Roads into the central regions are less developed than coastal roads and have many tight-radius turns and low capacity culverts. GEC expects that these road conditions will preclude the use of wind turbines larger than approximately $600 \mathrm{~kW}$ in the central region. The turbine blades are the greatest challenge due to length and the required turning radius. Large construction cranes are wide and quite heavy and in some cases can be the most challenging equipment to transport when constructing a utility-scale wind project.

Some of the coastal areas may have road access adequate for transporting turbine sizes up to $1 \mathrm{MW}$. Generally, the closer a wind project is to the coast, the less transportation is expected to be an issue. The 3-MW pilot wind project consists of $600-\mathrm{kW}$ turbines. Although the $600-\mathrm{kW}$ turbines posed some challenge, no significant road or bridge retrofits were required in transporting the equipment from Colombo to this south coast site.

\subsubsection{Construction Logistics}

Although Sir Lanka has some experience with large infrastructure projects, mobile construction cranes required for installing utility-scale wind equipment will be leased and barged over from the south coast of India. This appears to be a reasonable solution at least for the west coast of Sri Lanka. One of the private investment companies that considered bidding on the 20-MW CEB wind solicitation researched the cost and availability of using an Indian crane and determined that it was economically feasible.

While Sri Lanka has limited experience with utility-scale wind development, there is an adequate labor pool and experience with large infrastructure projects. Additional expertise may be available from India, which currently has more than 1,300 MW of installed wind capacity.

\subsubsection{Intra-Annual Variation in Wind Resource}

The wind resource in Sri Lanka is driven by the two monsoon seasons with the maximum winds coinciding with the wettest periods. This pattern is similar to the variations in the hydro resource that is used to generate the majority of electricity in the country. Therefore energy produced 
during the wet periods is of less value to CEB than energy produced during the dry periods. This is expected to be a slight disadvantage when wind power is compared to dispatchable thermal generation. As more of the electricity is produced from thermal sources, this issue will become less significant.

\subsection{Summary of Market Barriers}

Increased incentives specific to wind energy generation could facilitate the advancement of wind project development in Sri Lanka. Typical incentives include increased revenue tax holidays, production tax credits, and annual targets for renewable energy capacity or energy production.

Although CEB has experience with RFPs and PPAs, there are issues specific to wind energy development that require some consideration in order to ensure barriers are not inadvertently introduced that can hamper wind energy development. It is expected that the current review of the wind project RFP process will result in a tendering process that is more conducive to wind energy development.

The CEB grid operators are apprehensive about installing additional wind capacity since maintaining adequate grid stability and power quality is already difficult. Without detailed analysis, it is unclear how much total wind capacity can be added to the Sri Lanka grid or at any given point. Values used in this study are estimates from CEB. An analysis to determine the capacity for additional wind generation with respect to system stability and power quality should be carried out. The results of such an analysis may be used to update the estimated available capacity for wind power generation at each candidate site and of the system as a whole. This information can then be used in trade studies to identify the most cost-effective plan for wind power development that balances system upgrade costs with utilizing sites with the highest wind resource potential.

Although the construction logistics present some challenges and may limit turbine size, they do not preclude development of utility-scale wind energy projects. The specific limitations will need to be assessed on a site-to-site basis. The Road Development Authority is potentially a good resource for determining limitations on the country's main roads. 


\section{Site Screening Process}

To provide a mechanism for ranking and prioritizing areas with potential for utility-scale wind energy projects in Sri Lanka, GEC developed a site screening process to identify regions that may be suitable for wind energy development. The process is intended for use in siting commercial, utility-scale wind energy facilities of between 10 and $30 \mathrm{MW}$ in size. This size is consistent with the CEB-identified maximum level of wind power that the grid can accommodate in a particular region. Smaller facilities providing energy for rural and/or off-grid development applications are not specifically addressed in this process.

The screening process was developed based on techniques used in the United States that were adjusted for application in Sri Lanka as per information collected from CEB and other contacts as well as inspections of the central plains area of the country. The result of this work is a process that addresses wind resource evaluation, evaluation of land suitability and analysis of site-specific suitability. The following sections discuss each step in more detail.

The current internal conflict concerning the northern portion of Sri Lanka has been identified as a significant barrier for utility-scale wind power development. As a direct result of the conflict, the physical infrastructure in many northern locations is in poor condition, which presents technical barriers to increasing generation capacity in the region. Only site-specific limitations were evaluated in the site screening process, political barriers are discussed elsewhere in this report.

The following sections outline the site screening process and discuss appropriate considerations for each step in the process. The application of the site screening process to specific areas of Sri Lanka is then discussed in further detail in Section 5.

\subsection{Step 1 - Initial Screening of Wind Resource}

The most important factor in selecting a wind energy site is the wind resource itself. The wind resource in Sri Lanka primarily varies according to exposure to the monsoon winds. The southwest monsoon is stronger and penetrates farther inland and to higher elevations than the northeast monsoon.

A review of the NREL wind resource atlas and collected wind resource data for Sri Lanka indicates that regions with good exposure to the southwest monsoon and/or at high elevations have significant wind resources. The remaining regions, namely those with only exposure to the northeast-monsoon winds, are not expected to have wind resources sufficient for utility-scale wind power development.

Therefore, the first "screen" is to eliminate all sites that are not ranked by the NREL wind atlas as "Good" or better for utility applications (corresponding to a wind power density between 400 and $500 \mathrm{~W} / \mathrm{m}^{2}$ at $50 \mathrm{~m}$ height).

Note that a site's specific terrain features, vegetation and exposure will significantly impact the wind resource. As a result, many sites within areas ranked "Good" or better in the NREL maps may not actually have wind resources at the levels indicated. Within the areas defined as "Good" or "Excellent" by the NREL wind atlas, sites that are well exposed to the prevailing wind 
conditions should be identified. Generally these are immediate coastal sites with little vegetation or ridgelines and other high terrain features in the interior of the country.

The wind power density calculates the available wind energy of a site and therefore increases with the cube of the wind speed. Power output from a wind power project generally levels off above the wind turbine rated wind speed. Therefore the plant capacity factor is sensitive to the shape of the annual wind speed frequency distribution since times when the winds are greater than the rated wind speed do not result in appreciably more power output. To assess a site's wind power production potential, the wind speed frequency distribution must be multiplied by a representative wind turbine power curve. In addition to the wind power density, the annual wind speed frequency distribution for the sites investigated was considered when scoring the site's overall wind resource potential.

\subsection{Step 2 - Initial Screening for Land Suitability}

All land with a "Good" or better wind energy resource may not be suitable for wind energy development. An initial land suitability screening will eliminate sites where wind turbines either cannot or should not be installed. Factors that would eliminate a site from consideration include:

- National parks, wildlife sanctuaries or other areas where development is prohibited

- Migration routes of migratory bird species

- Areas with high concentrations of rare or endangered birds

- Urban areas

- Some military areas

- Culturally sensitive areas (religious, historic, or archeological sites)

Other site suitability issues are addressed by the next step in the process. In addition, sites will be subjected to an initial screening for transportation and transmission access.

\subsection{Step 3 - Factors Affecting Site Suitability}

There are many factors that affect site suitability. These factors, which will impact the costs and performance of a project and must be considered in the site selection process, are discussed below.

\subsubsection{Transmission Capacity and Accessibility}

Having a good wind energy resource will only be beneficial to a project's developers if the energy generated by the project can be cost effectively delivered to the organization purchasing the energy.

Even if it is possible to interconnect a site to a transmission system, the costs of such interconnections can be prohibitive. CEB's electrical transmission system should be evaluated and compared to the NREL wind atlas to identify areas with good wind resource and convenient transmission access. Consultations with CEB engineers will help identify transmission capacity limitations and interconnection constraints for the initial screening. Overlaying the NREL wind atlas on the transmission network maps will facilitate detailed investigations to identify areas with a strong wind resource and good transmission access. 
Other factors to consider in the evaluation of transmission options include whether transmission lines that have insufficient capacity to support a project can be upgraded through the use of new conductors, or alternative transmission paths can be arranged to open space on the lines. The stability of the transmission system at the project interconnection point also needs to be considered. If the grid is subjected to frequent outages or voltage/frequency excursions, the energy production from the site will be reduced.

Ultimately, it may be necessary to conduct a complete load flow study of the wind energy project interconnected to the transmission system, but this is not needed until later in the process of finalizing site selection.

\subsubsection{Site Terrain, Accessibility, and Complexity}

The more remote and/or complex the terrain, the higher the development cost is likely to be. This is because the more complex terrain will require more grading and earth movement than less complex terrain. Complex terrain may also limit the size of turbines that can be installed due to constraints in the ability to get the turbines or cranes to the site or to create sufficient lay-down areas for site construction. It can also lead to less-than-optimal turbine siting because terrain features affect the project layout.

The suitability of the roads between the port and the wind power project site for turbine equipment transportation can preclude areas for development or impact development costs if they require upgrades. The transportation routes for equipment should be evaluated and minimum bend radius, maximum grade, load capacity, minimum overhead clearance, and other properties should be determined. These values can then be compared to the requirements for standard equipment in order to asses the transportation feasibility and appropriate wind turbine size range for each particular site.

Inevitably some access roads will need to be installed for any site prior to site construction. The distance the wind project site is from major roads should be considered. Construction of access roads that are suitable for installation of a wind power plant can be expensive if long sections of new road are required or if the terrain is highly complex.

\subsubsection{Terrain Orientation to Prevailing Wind}

The orientation of the terrain features relative to the prevailing wind directions will heavily impact the site's capacity potential as well as its energy production. If the terrain features are conducive to a project layout that maximizes the number of turbines exposed to the prevailing winds while minimizing the array loss impacts, the site will have greater capacity and energy production than would otherwise be possible. For example, ridgelines that are perpendicular to the prevailing wind direction are preferred to ridgelines that are parallel to the prevailing wind direction. At sites with no clear prevailing direction, ridgelines limit the capacity that can be installed due to larger turbine spacing requirements than for sites that have a prevailing wind direction.

Wind turbines are typically arranged in rows perpendicular to prevailing winds. Within rows the spacing can vary from 1.5 to 5 times the rotor diameter. Row-to-row distances typically vary from 10 to 20 times the rotor diameter. If the wind is consistently from one direction (or the 
opposite compass direction), then within-row spacing is less and row-to-row spacing is greater. For sites that have energetic winds from multiple directions, the row-to-row spacing and withinrow spacing are similar.

\subsubsection{Nearby Resident's Concerns and Social Acceptability of Wind Energy Development}

If neighbors of the site under consideration are opposed to wind energy development on the site, the costs of development may increase significantly and the time required for project completion can also increase. Frequently, opposition to wind project development is based on incorrect information concerning the technology and when fully and accurately informed, development opponents become project supporters. The use of open forum informational meetings to obtain public input is suggested.

\subsubsection{Cost of Land}

Development of a project is dependent on having the rights to install turbines on the land. Land control generally is either obtained through a land-lease agreement or outright purchase of the land.

Approximately $90 \%$ of land in Sri Lanka is owned by the government and is typically available for 99-year lease at inexpensive rates. Similar cost sub-leases are expected to be available for land that is already leased. Therefore for this study, land costs were assumed to be the same for each site.

\subsubsection{On-Site Vegetation}

Vegetation increases the turbulence intensity at the site and decreases the wind speeds. While modern wind turbine towers are on the order of $60 \mathrm{~m}$ in height, the blade passage height can be $25 \mathrm{~m}$ or even less. Placing the turbines in areas with substantial vegetation over $10 \mathrm{~m}$ in height may increase the risk of turbulence-induced lost energy or damage to the turbines. Removal of heavy vegetation for site development can also increase project development cost and environmental impact.

\subsubsection{Soil Conditions}

Wind turbine foundations are typically reinforced concrete blocks or cylinders. Generally the most cost-effective designs require excavations 10-15 m deep. In addition, wind energy projects require roads and equipment pads sufficient to get the turbines to the sites and accommodate the cranes required to install the turbines. Soil conditions that are not readily excavated or graded can significantly increase project costs.

An additional consideration when examining site soil conditions is erosion. Controlling erosion will be more difficult for some combinations of soils, weather conditions and terrain than others.

\subsubsection{Cultural and Environmental Concerns}

Protected or endangered flora and fauna can increase the costs of wind energy project development. Generally, projects can be built in a manner that minimizes the impact of the project on these species; however, this takes time and money. All other factors being equal, sites 
with no endangered or protected species are preferred to sites containing endangered or protected species.

Development of sites that have cultural significance may be offensive to some parties. These concerns can increase costs or delay a project and should be considered in the site selection process. Examples of cultural significance include burial, religious, historical, or archeological sites.

\subsubsection{Aviation/Telecommunications Conflicts}

Sites located close to airports or telecommunications facilities must be installed in a manner that accommodates these activities.

\subsubsection{Site Capacity}

The ability of the site to accommodate the planned project size and potential future expansion must be considered. This is particularly true if a significant investment in transmission system upgrades is required to deliver energy from the project to the site. The site's capacity must be determined using turbines that can be transported to and erected on the site. Generally, more complex terrain will be more optimally developed with relatively smaller turbines because larger cranes and trucks are needed for larger turbines. Capacity is generally affected by the amount of terrain that is relatively high compared to the surrounding area, such as long ridgelines or plateaus. Areas with more isolated hilltops offer fewer ideal locations for turbines and hence may have less potential capacity.

\subsection{Step 4 - Preliminary Site Ranking}

To facilitate the application of the screening criteria developed above, a preliminary spreadsheet was developed to assign a relative score to each of the key ranking criteria. The screening criteria and ranking process are presented in Table 4-1.

To apply the site screening process, each criterion is assigned a score based on Table 4-1. The score assigned to the wind resource potential is weighted (multiplied) by a factor of 5 and added to the remaining scores. This weighting reflects the relative importance of the wind resource in selecting a wind energy site. The cumulative scores for the sites are then compared. Sites that receive high scores have more favorable conditions for development of utility-scale wind projects than sites with lower scores. Note that the maximum possible score for each criterion is not the same. The differences reflect the relative importance of the criteria. For example, wind resources of $500-600 \mathrm{~W} / \mathrm{m}^{2}$ ( 3 points $\mathrm{x} 5=15$ points) will have a more significant impact on a project's economics than a site with significant vegetation (1 point). Clearly, assigning rankings is somewhat subjective and may vary between sites. However, they provide a coarse filter by which sites can be ranked. 
Table 4-1. Site Ranking Criteria

\begin{tabular}{|l|l|l|l|l|l|}
\hline \multicolumn{4}{|c|}{ Points Assigned (Score) } \\
\hline Criteria & \multicolumn{1}{|c|}{$\mathbf{1}$} & \multicolumn{1}{|c|}{$\mathbf{2}$} & \multicolumn{1}{|c|}{$\mathbf{3}$} & \multicolumn{1}{|c|}{$\mathbf{4}$} \\
\hline Wind resource density at 50 m based on NREL atlas & $<400$ & $400-500$ & $500-600$ & $600-800$ & $>800$ \\
\hline Proximity to transmission lines & $>20 \mathrm{~km}$ & $10-20 \mathrm{~km}$ & $5-10 \mathrm{~km}$ & $1-5 \mathrm{~km}$ & $<1 \mathrm{~km}$ \\
\hline Transmission/interconnection capacity \& grid stability & Poor & Marginal & Satisfactory & Good & Excellent \\
\hline Terrain & Rugged & Complex & Moderate & Rolling & Flat \\
\hline Accessibility & Poor & Marginal & Upgradeable & Good & Excellent \\
\hline Terrain orientation to prevailing wind & Poor & Marginal & Satisfactory & Good & Excellent \\
\hline Neighbor or community concerns & High & & Moderate & & Low \\
\hline Social acceptability & Poor & & Satisfactory & & Excellent \\
\hline Land costs & High & & Moderate & & Low \\
\hline Vegetation over 10 m & Significant & & Scattered & & None \\
\hline Soil conditions & Solid Rock & Fractured Rock & Rock/Soil & Soil/Rock & All Soil \\
\hline Site environment issues (corrosion, humidity) & Extensive & Moderate & Average & Minor & None \\
\hline Cultural or environmental concerns & Extensive & & Moderate & & None \\
\hline Aviation and telecommunications conflicts & Extensive & & Moderate & & None \\
\hline
\end{tabular}

\subsection{Step 5 - Quantitative Site Assessment}

Application of the preceding process to a series of sites provides a qualitative ranking. To refine the process, it is ultimately necessary to conduct a more detailed economic analysis of prospective sites using these results. The specific approach to this activity will depend somewhat on the objectives. Generally, the objective will be to obtain the lowest possible cost of energy.

Assuming that mature, commercial wind turbines are used for any project under consideration, the two cost-of-energy related variables that will be affected by the project site are the initial project cost and the annual energy production. Given the lack of significant tax holidays and incentive structures for wind energy in Sri Lanka, it can be assumed that small changes in the annual energy production from a project will have approximately the same proportional impact on the cost of energy as in initial project cost. This relationship can be used to assess how changes in either parameter will impact the relative cost of energy from two sites.

For the purposes of estimating the increase in energy production, a multiplier of approximately 2 applied to the percentage variance in wind speed is appropriate. For example, a $10 \%$ increase in wind speed will generally result in roughly a $20 \%$ increase in energy production. The following example illustrates this approach.

Site A and Site B are identical in all ways except that site A has a five percent (5\%) higher wind speed than site $\mathrm{B}$ and is $20 \mathrm{~km}$ further from existing transmission lines. A 10-MW wind energy project is being considered for both sites. It is estimated that the cost to build the project at site $\mathrm{B}$ is $\$ 12$ million. Transmission line construction costs are estimated to be $\$ 50,000$ per $\mathrm{km}$. The cost of the transmission line for site A will therefore add $\$ 1$ million $(8 \%)$ to the cost of the project. Due to the non-linear relationship between wind speed and energy production from a wind power plant, the 5\% higher wind speed at site A will result in at least a $10 \%$ increase in energy production relative to site $\mathrm{B}$. For the purposes of site screening, site A would be preferred to site B because the 
increase in project cost due to the transmission line $(8 \%)$ is a smaller percentage than the increase in energy production from the higher wind speeds $(10 \%)$.

This information is useful when screening project sites because it allows changes in factors that impact annual revenue (such as the power purchase contract and the wind resource) to be compared against changes in factors that impact project initial cost (such as transmission upgrades, terrain complexity and turbine price) without developing comprehensive project financial models and detailed cost estimates. Clearly, more detailed work in assessing a project site produces a higher level of confidence in the assessment; however, for the purpose of site screening, a relatively coarse estimate may be all that is required. 


\section{Initial Screening of Potential Wind Power Generation Sites}

By applying the site screening process, collecting information from CEB and other personnel and visiting the Central High Plains and other areas of Sri Lanka, an initial assessment of the entire country for the relative feasibility of wind power project development was conducted. Sites that at least showed "Good" wind resource potential and were suitable for development were then ranked according to their feasibility for development.

Many locations in the Central Province that are shown to have "Excellent" wind resource potential on the NREL maps were not analyzed due to their extremely rugged terrain and inaccessibility. Locations above $914 \mathrm{~m}$ in the Knuckles Range were excluded from analysis because development is prohibited to preserve protected plant and animal species.

Site screening results are shown for each site in Table 5-1 to Table 5-5. When evaluating large areas, reasonable best-case values were used to determine the appropriate score for each criterion.

\subsection{Southeast Coast - Hambantota to Buthawa}

The wind resource of this region has been studied more than any other region in the country [2]. The wind resource potential on the immediate coastal sites between Hambantota and Buthawa are expected to be Class 4 but the wind speeds diminish considerably inland. The NREL wind maps and other measurements indicate that a few kilometers and farther inland from the coast the wind resource potential falls to Class 2 or lower.

A large portion of the areas with Class 4 wind resource potential in this region is national park or reserve land where development is severely restricted. Wind farm development may be difficult to permit on the remaining land due to the proximity to park and reserve land.

Sri Lanka's only utility-scale wind power project, a 3-MW pilot project, is located near Hambantota although several kilometers inland from the southeast coast. The site chosen is different from the sites analyzed in CEB feasibility study in order to distance the project from national park and reserve land. The current site has a lower wind resource than the sites recommended in CEB study and lower than coastal sites. The performance of the wind farm illustrates the importance of significant wind resource differences over short distances in this region. In 2000 , the capacity factor for the pilot wind project was $12.8 \%$, which reflects the relatively low wind resource at the project site. [5].

Transportation access for wind power equipment to the southeast coast is better than many areas of the country. CEB successfully transported $600-\mathrm{kW}$ turbines to Hambantota as part of the pilot project construction. It may be possible to transport larger machines to the same region after minor road upgrades or to transport the equipment by barge.

The substation serving the Hambantota and surrounding area has undergone recent upgrades and according to CEB has capacity available for more wind generation. An exact level of capacity remaining on the substation is not known although CEB estimates the capacity to be approximately $30 \mathrm{MW}$. Like other areas in the country, CEB estimates that additional wind- 
generated capacity in excess of $20 \mathrm{MW}$ in the southeast coastal region may lead to further system instability. Therefore the local potential for wind power capacity will most likely be driven by grid stability issues over available land, transportation and other factors. Grid-impact studies may conclude that a larger project can be installed with minimal impact in this area.

Figure 5-1 shows the southeast coastal area and Table 5-1 list the results of the site evaluation for the southeast coastal area.

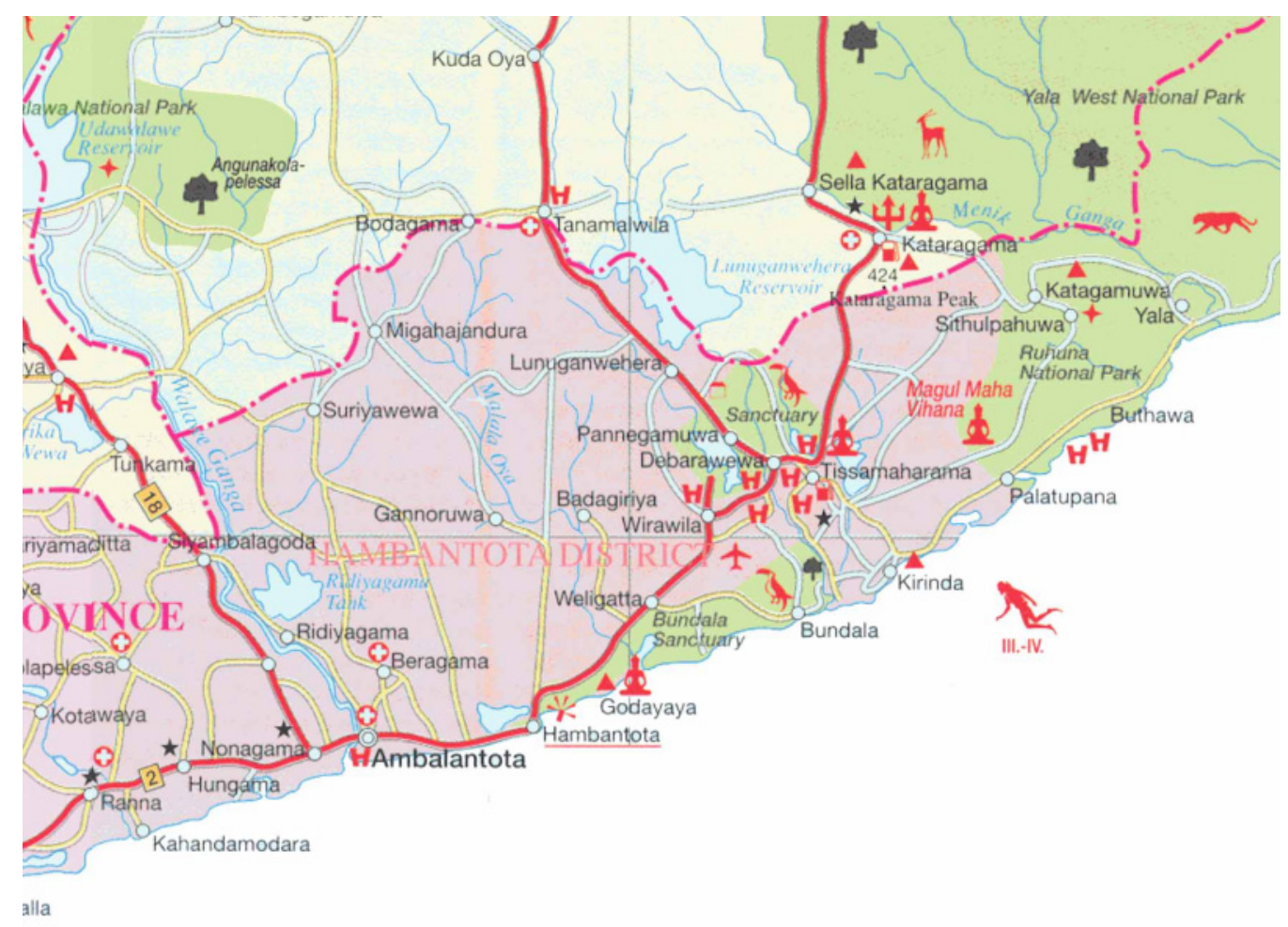

Figure 5-1. Southeast Coast Area 
Table 5-1. Southeast Coast Site Evaluation Results

\begin{tabular}{|c|c|c|}
\hline Criteria & $\begin{array}{c}\text { Score } \\
\text { (5 Excellent) }\end{array}$ & Comments \\
\hline $\begin{array}{l}\text { Wind resource density based } \\
\text { on NREL atlas }\end{array}$ & 2 & $\begin{array}{l}\text { Immediate coastal locations near Hambantota are basis for resource score } \\
\text { NREL wind atlas identified a Class } 4 \text { wind resource on the coast. }\end{array}$ \\
\hline Proximity to transmission lines & 4 & Transmission lines within $5 \mathrm{~km}$ of most areas. \\
\hline $\begin{array}{l}\text { Transmission/interconnection } \\
\text { capacity and grid stability }\end{array}$ & 3 & $\begin{array}{l}\text { Hambantota has new substation with capacity for a } 30-\mathrm{MW} \text { project } \\
\text { interconnection, according to CEB estimate. Transmission line capacity } \\
\text { sufficient for } 30 \mathrm{MW} \text { of added capacity. Local grid stability and outages are } \\
\text { issues and may preclude projects larger than } 20 \mathrm{MW} \text {. }\end{array}$ \\
\hline Terrain & 5 & Flat or gently rolling (dunes) terrain near the coast. \\
\hline Accessibility & 4 & $\begin{array}{l}\text { Roads sufficient to transport at least } 600-\mathrm{kW} \text { machines, possibly up to } \\
1 \mathrm{MW} \text {. Barge may be more feasible for turbines larger than } 600 \mathrm{~kW} \text {. }\end{array}$ \\
\hline $\begin{array}{l}\text { Terrain orientation to } \\
\text { prevailing wind }\end{array}$ & 3 & $\begin{array}{l}\text { Winds parallel to coast. Turbines would need to be oriented in rows } \\
\text { perpendicular to coast, which is less efficient than if the rows could be } \\
\text { parallel to the coast. }\end{array}$ \\
\hline $\begin{array}{l}\text { Neighbor/community concerns } \\
\text { \& social acceptability }\end{array}$ & 5 & Pilot project in same area is well accepted. \\
\hline Land costs & 5 & Low-cost 99-year leases available from government. \\
\hline Vegetation over 10 meters & 5 & Vegetation typically low-level ( $\sim 5 \mathrm{~m})$ scrub jungle. \\
\hline Soil conditions & 5 & Mostly soil. \\
\hline $\begin{array}{l}\text { Site environment issues } \\
\text { (corrosion, humidity) }\end{array}$ & 2 & Corrosive environment. \\
\hline $\begin{array}{l}\text { Cultural or environmental } \\
\text { concerns }\end{array}$ & 3 & $\begin{array}{l}\text { Pilot project has shown negligible environmental impact. Land availability } \\
\text { limited by wildlife refuges in area. }\end{array}$ \\
\hline Aviation \& telecomm conflicts & 5 & No apparent conflicts. \\
\hline
\end{tabular}

\subsection{West Coast - Kalpitiya Peninsula}

One-year average wind speeds up to $7.13 \mathrm{~m} / \mathrm{s}$ at $40-\mathrm{m}$ height were measured on the Kalpitiya Peninsula from 2000 to 2001 [3]. The NREL maps indicate a Class 5 wind resource potential exists over the northern half of the peninsula and the nearby islands.

Figure 5-2 shows the Kalpitiya Peninsula and the Puttalam area on the west coast of Sri Lanka.

The Kalpitiya Peninsula is composed of generally flat sand tracts that support low-grown vegetation and some coconut plantations. This region is well exposed to both the southwest and northeast monsoon winds. There are no national park or reserve lands on the peninsula and ample territory for large utility-scale wind power projects.

CEB has released a Request for Proposal (RFP) for a 20-MW wind power project to be presented on a build, operate and own basis. The Kalpitiya and Hambantota areas were identified as the possible locations for the projects. The bidders are responsible for choosing the exact location for the project. At the time of writing, a winning bidder has not been identified; however, CEB expects most or all projects to be proposed for the Kalpitiya area.

CEB estimates that the existing Puttalam substation can accommodate up to $20 \mathrm{MW}$ of wind power capacity. If the planned 20-MW wind farm is installed in the Puttalam area, the local wind power potential will be exhausted unless the substation were upgraded and it can be assured that additional wind capacity will not degrade grid stability. 
Transportation access for wind power equipment to the Kalpitiya Peninsula is better than many areas of the country. It is expected that turbines up to $1 \mathrm{MW}$ in size can be transported to this region either via moderately improved roads or by barge. Table 5-2 lists the Kalpitiya Peninsula site evaluation results.

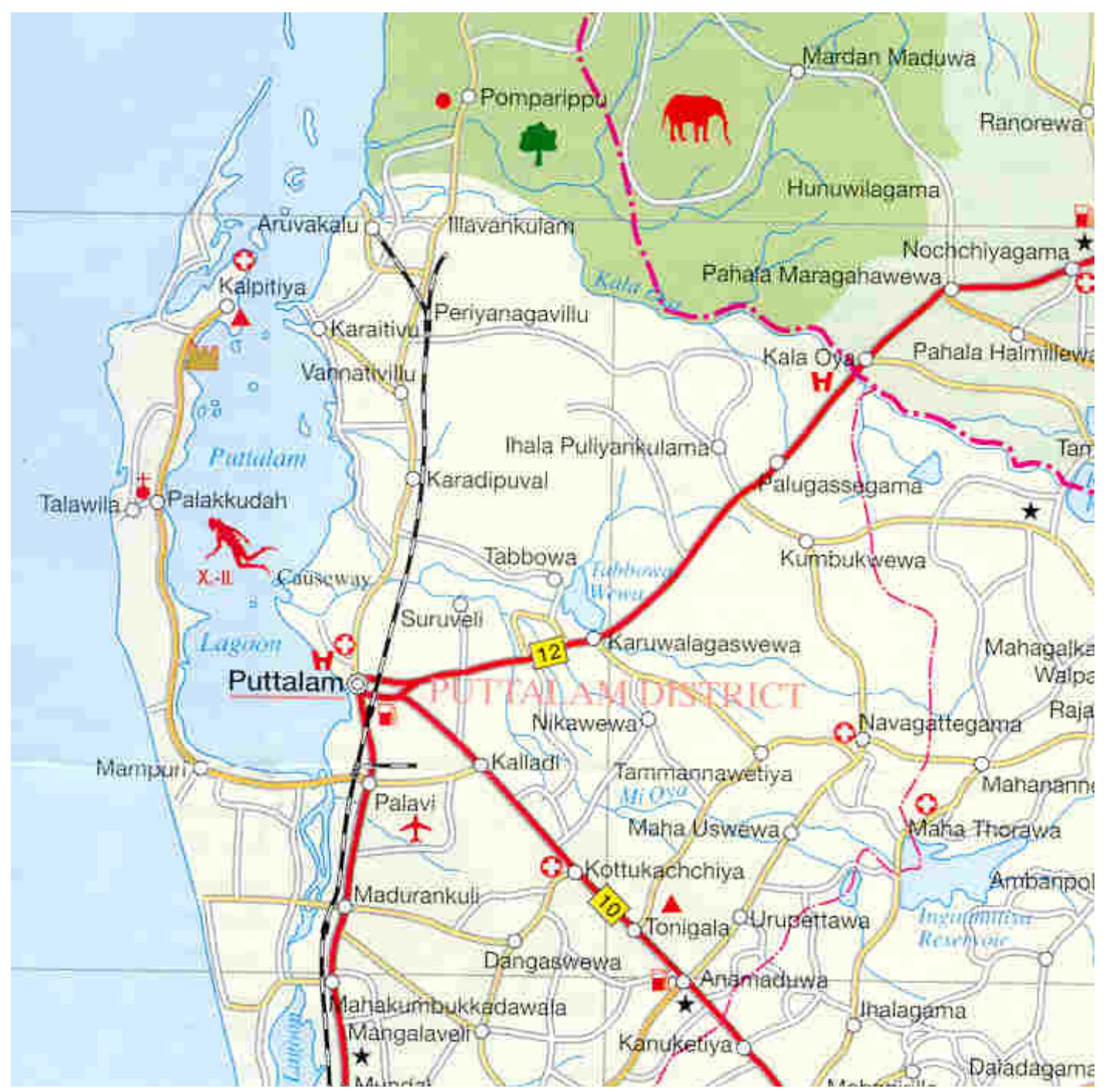

Figure 5-2. Kalpitiya Peninsula and Puttalam Area 
Table 5-2. Kalpitiya Peninsula Site Evaluation Results

\begin{tabular}{|c|c|c|}
\hline Criteria & $\begin{array}{c}\text { Score } \\
\text { (5 Excellent) }\end{array}$ & Comments \\
\hline $\begin{array}{l}\text { Wind resource density based on } \\
\text { NREL atlas }\end{array}$ & 3 & $\begin{array}{l}\text { Kalpitiya Peninsula coastal locations are basis for resource } \\
\text { score. NREL wind atlas identified wind resource potential as } \\
\text { Class } 5 \text { in area. }\end{array}$ \\
\hline Proximity to transmission lines & 4 & Transmission lines within $5 \mathrm{~km}$ of most areas. \\
\hline $\begin{array}{l}\text { Transmission/interconnection } \\
\text { capacity and grid stability }\end{array}$ & 1 & $\begin{array}{l}\text { Planned } 20-\mathrm{MW} \text { wind farm will use up existing substation } \\
\text { capacity and additional local generation beyond the planned } \\
20-\mathrm{MW} \text { wind farm may cause stability issues. }\end{array}$ \\
\hline Terrain & 5 & Flat or gently rolling (dunes) terrain near the coast. \\
\hline Accessibility & 4 & $\begin{array}{l}\text { Roads sufficient to transport at least } 700-\mathrm{kW} \text { machines. } \\
\text { Barge can be used for larger turbines or road would require } \\
\text { improvement. }\end{array}$ \\
\hline $\begin{array}{l}\text { Terrain orientation to prevailing } \\
\text { wind }\end{array}$ & 4 & $\begin{array}{l}\text { Good exposure to southeast monsoon winds but poor } \\
\text { exposure to northeast monsoon winds. }\end{array}$ \\
\hline $\begin{array}{l}\text { Neighbor or community } \\
\text { concerns and social } \\
\text { acceptability }\end{array}$ & 3 & Some local opposition to planned 20-MW wind farm. \\
\hline Land costs & 5 & Low-cost 99-year leases available from government. \\
\hline Vegetation over 10 meters & 5 & Vegetation typically low-level ( $\sim 5 \mathrm{~m})$ scrub jungle. \\
\hline Soil conditions & 5 & Mostly soil. \\
\hline $\begin{array}{l}\text { Site environment issues } \\
\text { (corrosion, humidity) }\end{array}$ & 2 & Corrosive environment. \\
\hline $\begin{array}{l}\text { Cultural or environmental } \\
\text { concerns }\end{array}$ & 5 & $\begin{array}{l}\text { Few wildlife refuges etc. in proximity. Concerns small as } \\
\text { compared to some other regions. }\end{array}$ \\
\hline Aviation and telecomm conflicts & 5 & No apparent conflicts. \\
\hline
\end{tabular}




\subsection{Northwest Coast - Mannar Island}

Mannar Island is a flat and featureless island that juts into the Palk Straight on the northwest coast of Sri Lanka. No known wind resource measurements have been made on the island. The NREL maps indicate the wind resource potential is Class 5 over most of Mannar Island.

There are considerable areas with good wind resource potential and little potential for land use conflicts on Mannar Island. The road and utility infrastructure on Mannar Island is in poor condition due to the regional conflict. Near-term wind power development is unlikely to be feasible until the region stabilizes and the infrastructure is repaired and upgraded. Table 5-3 shows the Mannar Island site evaluation results.

Table 5-3. Mannar Island Site Evaluation Results

\begin{tabular}{|c|c|c|}
\hline Criteria & $\begin{array}{c}\text { Score } \\
\text { (5 Excellent) }\end{array}$ & Comments \\
\hline $\begin{array}{l}\text { Wind resource density based on } \\
\text { NREL atlas }\end{array}$ & 3 & $\begin{array}{l}\text { Mannar Island is basis for resource score. NREL wind atlas } \\
\text { identified wind resource potential as Class } 5 \text { on most of the } \\
\text { island. }\end{array}$ \\
\hline Proximity to transmission lines & 1 & $\begin{array}{l}\text { Transmission lines are currently in poor condition and in } \\
\text { limited operation. }\end{array}$ \\
\hline $\begin{array}{l}\text { Transmission/interconnection } \\
\text { capacity and grid stability }\end{array}$ & 1 & Local grid interconnection is in disrepair. \\
\hline Terrain & 5 & Flat or gently rolling (dunes) terrain near the coast. \\
\hline Accessibility & 1 & Roads are in severe disrepair. \\
\hline $\begin{array}{l}\text { Terrain orientation to prevailing } \\
\text { wind }\end{array}$ & 5 & Good exposure to southeast and northeast monsoon winds. \\
\hline $\begin{array}{l}\text { Neighbor or community } \\
\text { concerns and social } \\
\text { acceptability }\end{array}$ & 1 & $\begin{array}{l}\text { Property associated with the government may be target for } \\
\text { vandalism as a result of the current conflict. }\end{array}$ \\
\hline Land costs & 5 & Low-cost 99-year leases available from government. \\
\hline Vegetation over 10 meters & 5 & Vegetation typically low-level ( $\sim 5 \mathrm{~m})$ scrub jungle. \\
\hline Soil conditions & 5 & Mostly soil. \\
\hline $\begin{array}{l}\text { Site environment issues } \\
\text { (corrosion, humidity) }\end{array}$ & 2 & Corrosive environment. \\
\hline $\begin{array}{l}\text { Cultural or environmental } \\
\text { concerns }\end{array}$ & 5 & $\begin{array}{l}\text { Few wildlife refuges, etc., in proximity. Concerns small as } \\
\text { compared to some other regions. }\end{array}$ \\
\hline Aviation and telecomm conflicts & 5 & No apparent conflicts. \\
\hline
\end{tabular}




\subsection{North Coast - Jaffna}

The Jaffna District in the far north of Sri Lanka is a flat peninsula and group of islands that extends into the Palk Straight. The NREL maps indicate the wind resource potential on some islands and the coast near Jaffna City are Class 5. Class 4 wind resource potential is indicated along the remaining coastal areas with Class 3 winds inland. No known wind resource measurements have been made on the island. Figure 5-3 shows the Jaffna District and surroundings.

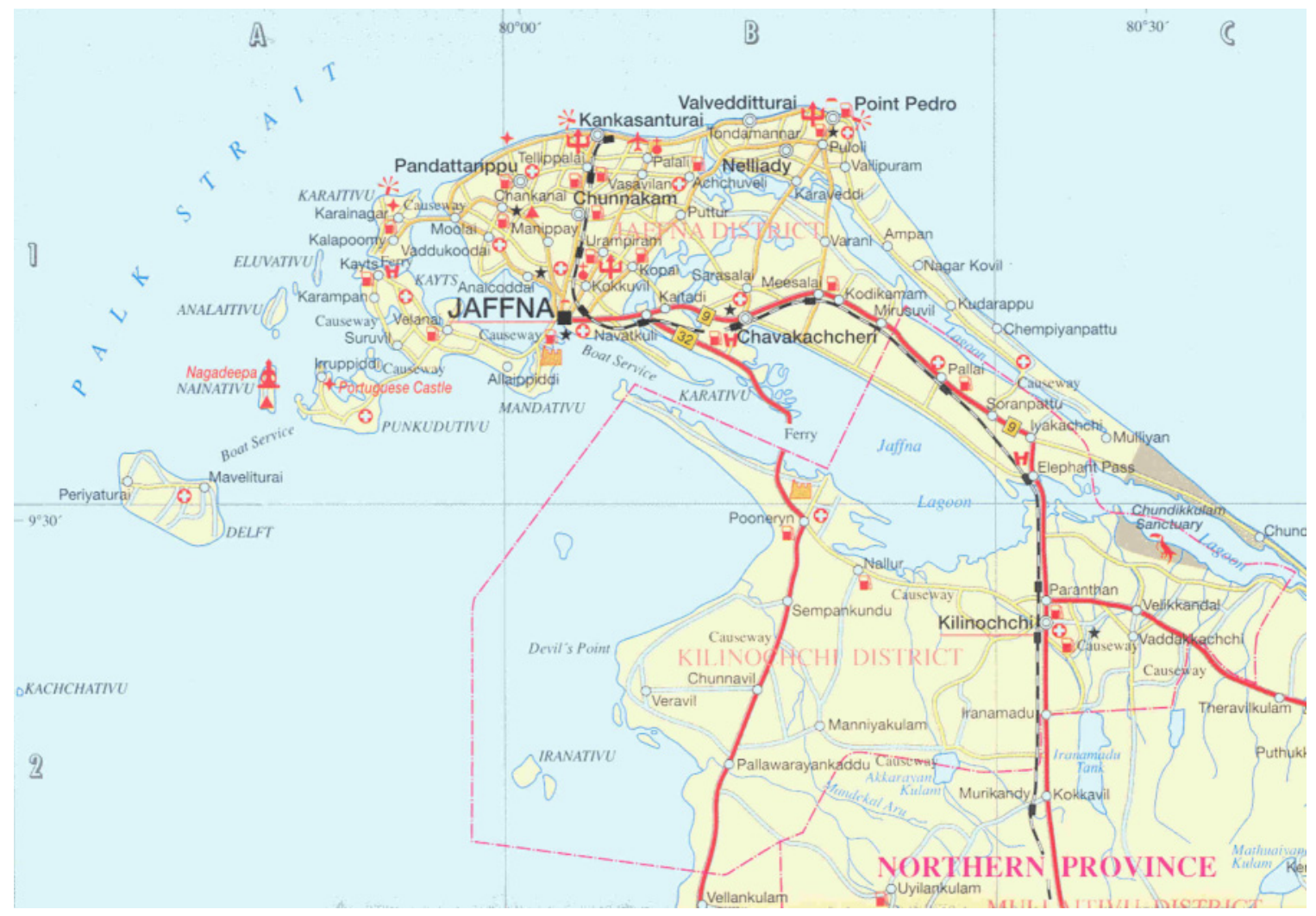

Figure 5-3. Jaffna District

The regional conflict in the northern portion of Sri Lanka has affected Jaffna considerably. The road and utility infrastructure in the region has suffered as a result. As for Mannar Island, nearterm wind power development is unlikely to be feasible until the region stabilizes and the infrastructure is repaired and upgraded. Most of the Class 5 wind resource potential areas in Jaffna District are on islands, which may complicate development considerably. Table 5-4 shows the Jaffna District site evaluation results. 
Table 5-4. Jaffna Site Evaluation Results

\begin{tabular}{|c|c|c|}
\hline Criteria & $\begin{array}{c}\text { Score } \\
\text { (5 Excellent) }\end{array}$ & Comments \\
\hline $\begin{array}{l}\text { Wind resource density based on } \\
\text { NREL atlas }\end{array}$ & 3 & $\begin{array}{l}\text { Islands and coastal locations Near Jaffna City are basis for } \\
\text { resource score. NREL wind atlas identified wind resource } \\
\text { potential as Class } 5 \text { in limited areas but large enough for at } \\
\text { least a } 20-\mathrm{MW} \text { project. }\end{array}$ \\
\hline Proximity to transmission lines & 1 & $\begin{array}{l}\text { Transmission lines are currently in disrepair and limited } \\
\text { operation. }\end{array}$ \\
\hline $\begin{array}{l}\text { Transmission/interconnection } \\
\text { capacity and grid stability }\end{array}$ & 1 & Local grid interconnection is in disrepair. \\
\hline Terrain & 5 & Flat or gently rolling terrain near the coast and on islands. \\
\hline Accessibility & 1 & $\begin{array}{l}\text { Roads are in severe disrepair and transportation of heavy } \\
\text { equipment to islands may be difficult. }\end{array}$ \\
\hline $\begin{array}{l}\text { Terrain orientation to prevailing } \\
\text { wind }\end{array}$ & 5 & $\begin{array}{l}\text { Good exposure to southeast and northeast monsoon winds } \\
\text { in Class } 5 \text { areas. }\end{array}$ \\
\hline $\begin{array}{l}\text { Neighbor or community } \\
\text { concerns and social } \\
\text { acceptability }\end{array}$ & 1 & $\begin{array}{l}\text { Property associated with the government may be target for } \\
\text { vandalism as a result of the current conflict. }\end{array}$ \\
\hline Land costs & 5 & Low-cost 99-year leases available from government. \\
\hline Vegetation over 10 meters & 5 & Vegetation typically low-level ( $5 \mathrm{~m})$ scrub jungle. \\
\hline Soil conditions & 5 & Mostly soil. \\
\hline $\begin{array}{l}\text { Site environment issues } \\
\text { (corrosion, humidity) }\end{array}$ & 2 & Corrosive environment. \\
\hline $\begin{array}{l}\text { Cultural or environmental } \\
\text { concerns }\end{array}$ & 5 & $\begin{array}{l}\text { Few wildlife refuges, etc., in proximity. Concerns small as } \\
\text { compared to some other regions. }\end{array}$ \\
\hline Aviation and telecomm conflicts & 5 & No apparent conflicts. \\
\hline
\end{tabular}

\subsection{Central Province - Ambewela}

Most of the terrain in the Central Province is too rugged and inaccessible to be developed for wind power and much of the higher elevation land with Class 6 and better wind resource potential is restricted to development for natural preservation reasons. However, there are several large high plains that the NREL maps indicate have a wind resource potential of Class 5 or better and have terrain that is suitable for utility-scale wind power project development. Some of these plains are currently used as cattle farms which historically have proven to be compatible with wind power projects. Of these sites, one of the most promising for utility-scale wind power development identified in the area is the National Livestock Development Board cattle farm near Ambewela. Figure 5-4 shows the approximate location of the Ambewela cattle farm site. 


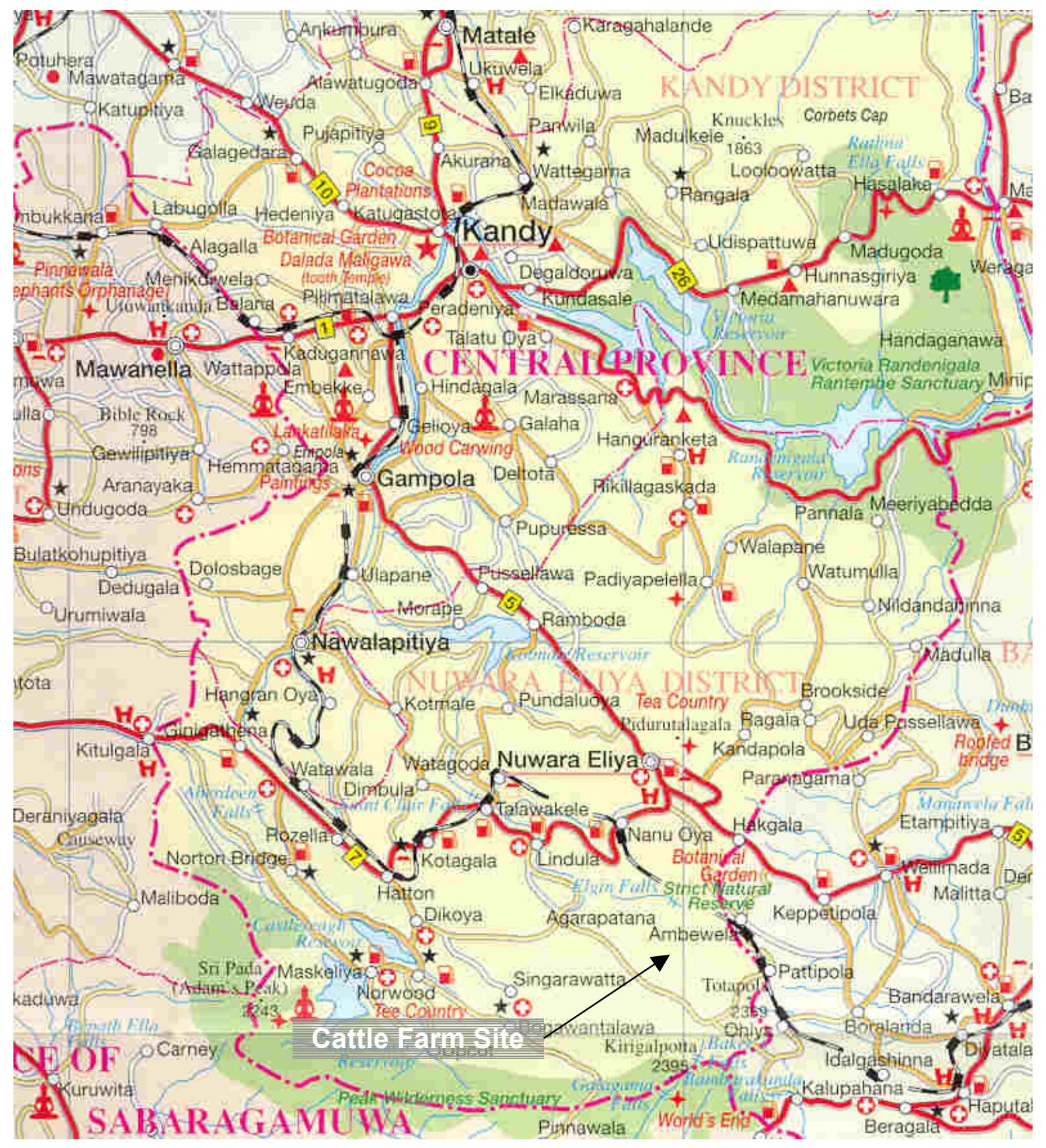

Figure 5-4. Ambewela Cattle Farm Location

GEC conducted a site visit to the Ambewela cattle farm to inspect the meteorological tower located on the site. The cattle farm is located on a large rolling plain with an area of approximately $10 \mathrm{~km}^{2}$ at an elevation of about $1800 \mathrm{~m}$. The cattle farm terrain is fairly complex with many rolling hills of varying, although moderate, steepness, but with little terrain variation more than $40 \mathrm{~m}$ from the mean elevation. The primary vegetation is tall grass; however, some isolated small trees less than $5 \mathrm{~m}$ in height dot the landscape. There are several clusters of taller (est. 15-m height) trees on the edges of the cattle farm. 
As with most sites in Sri Lanka, the annual wind direction distribution is very directional and consistent with either the southwest monsoon winds from May to October or the northeast monsoon winds from December to February. Inter-monsoonal winds are generally light and variable.

An average wind speed of $7.31 \mathrm{~m} / \mathrm{s}$ at $40 \mathrm{~m}$ height was measured at this site from November 2000 to October 2001 [3]. An extreme intra-annual variation in the mean wind speed at this site was measured. The southwest monsoon winds were very strong at this site, resulting in measured average wind speeds between 7.9 and $14.7 \mathrm{~m} / \mathrm{s}$ between May and October 2001. Measured average wind speed varied between 3.9 and $4.4 \mathrm{~m} / \mathrm{s}$ between December 2000 and February 2001. The NREL analysis in support of the wind atlas creation also indicates that the northeast monsoon winds are attenuated considerably at the altitude of this site resulting in a broad annual wind speed frequency distribution with a Weibull $\mathrm{k}$ value of 1.2. The NREL maps indicate a wind resource potential of Class 6 in this area. The wind power density class tends to over predict the wind power production potential of this area since a significant amount of time is spent above typical turbine rated wind speeds during the wind season. This area is expected to have a similar but lower wind power production potential than the Kalpitiya Peninsula.

The Ambewela cattle farm meteorological tower is located on the leeward (northeast) side of the plain in terrain that is slightly less complex than the windward (southwest) side but at a lower elevation. Figure 5-5 shows the meteorological site and the surrounding terrain.

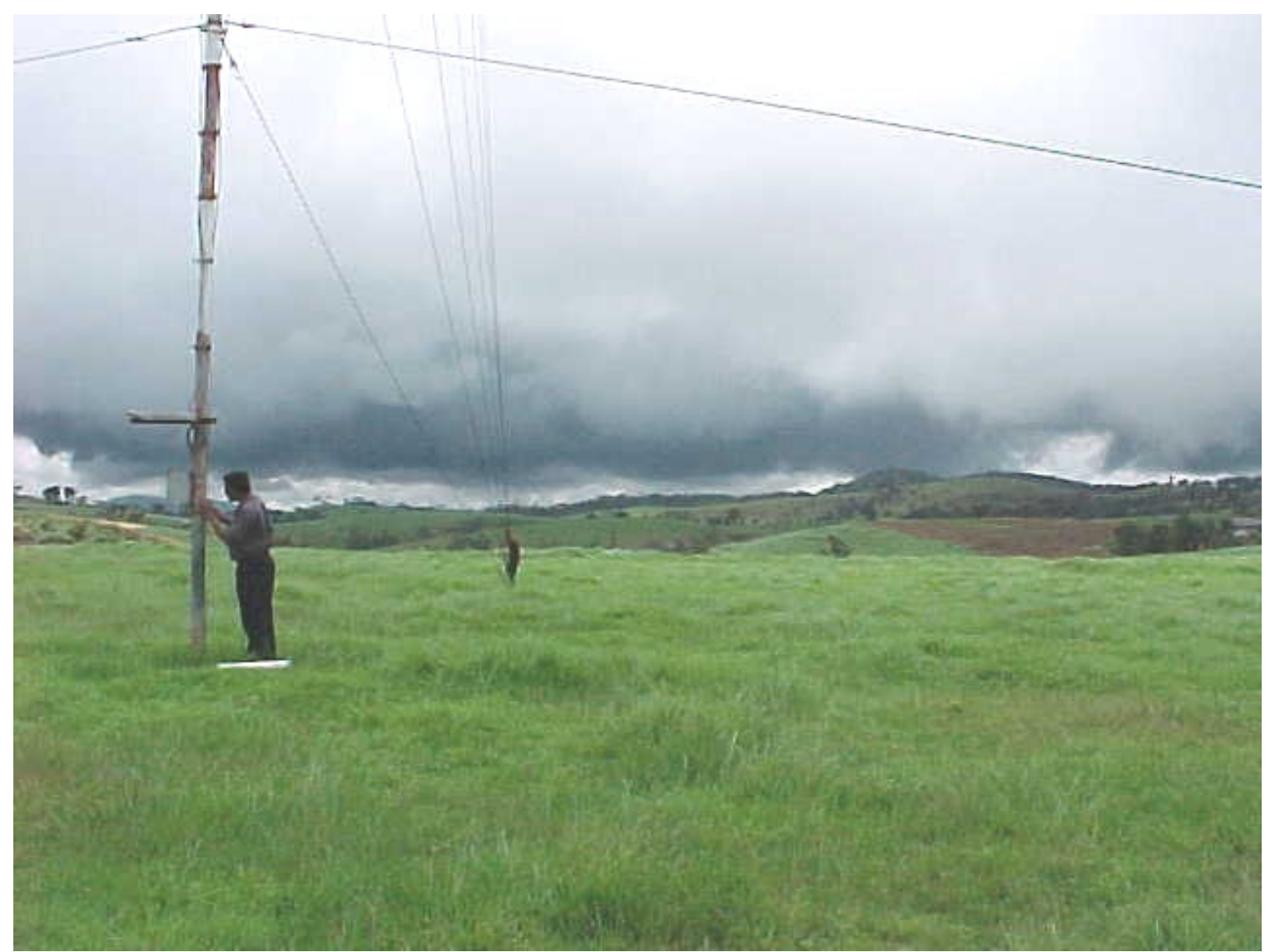

Figure 5-5. Ambewela Cattle Farm Meteorological Site - Southwest View 
The cattle farm site is only a few kilometers from a $33-\mathrm{kW}$ line that, according to CEB, would be suitable for interconnection of a 20- to 30-MW wind farm. The physical area on the cattle farm is expected to be able to support a wind project of more than $80 \mathrm{MW}$; however, like all other locations in the country, wind capacity in excess of $20 \mathrm{MW}$ may negatively impact grid stability. Since this site would interconnect to a relatively stable part of the grid, a project up to $30 \mathrm{MW}$ may be feasible. Grid-impact studies may conclude that a larger project can be installed with minimal impact in this area.

One of the major obstacles to wind power development in the central province is the poor quality of roads in the region. Highway 7 provides the most direct and highest capacity highway access from the Columbo Port to Nuwara Eliya which is $15 \mathrm{~km}$ north-northwest of the Ambewela cattle farm site. This route includes several small-radius hairpin turns, narrow culverts, steep inclines with sharp transitions and narrow sections.

Figure 5-6 shows a turn and culvert on Highway 7. Several other similar turns and culverts are present on Highway 7. It is expected that Highway 7 would need some improvements to allow the passage of utility-scale wind power equipments. Turbines larger than about $500 \mathrm{~kW}$ may require significant improvements to Highway 7. The road from Nuwara Eliya to the site may also require improvements, but to a lesser extent than Highway 7.

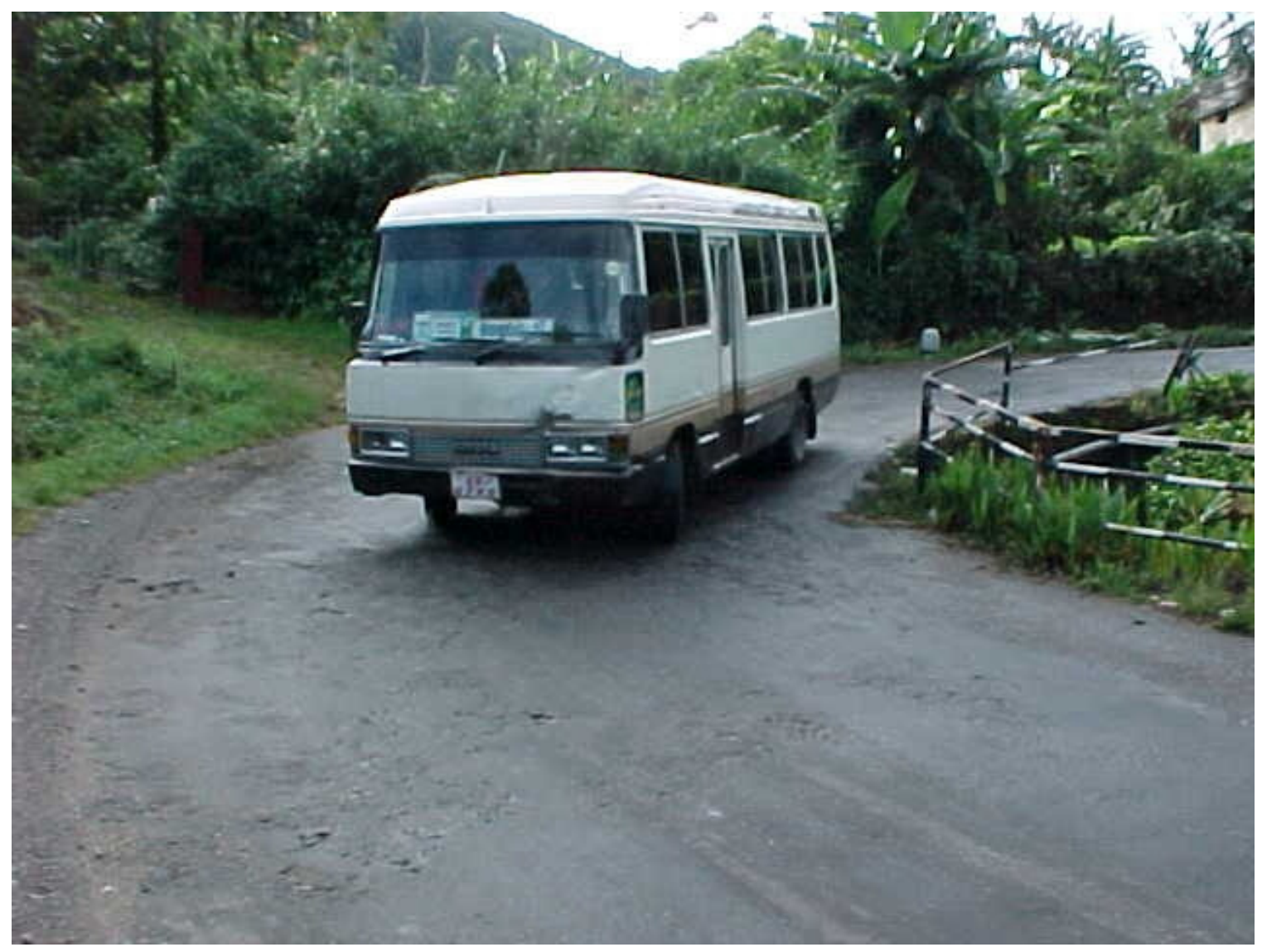

Figure 5-6. Typical Turn and Culvert on Highway 7 
Table 5-5 lists the results of the site evaluation for the Ambewela cattle farm site.

Table 5-5. Ambewela Cattle Farm Site Evaluation Results

\begin{tabular}{|c|c|c|}
\hline Criteria & $\begin{array}{c}\text { Score } \\
\text { (5 Excellent) }\end{array}$ & Comments \\
\hline $\begin{array}{l}\text { Wind resource density based on } \\
\text { NREL atlas }\end{array}$ & 3 & $\begin{array}{l}\text { Ambewela cattle farm met site is basis for resource score. } \\
\text { NREL wind atlas identified local wind resource potential as } \\
\text { Class } 6 . \text { Higher wind power density than Kalpitiya but lower } \\
\text { Weibull k value is expected to result in lower capacity factor, } \\
\text { therefore score is downgraded from } 4 \text { to } 3 . \text {. }\end{array}$ \\
\hline Proximity to transmission lines & 4 & Transmission lines within $5 \mathrm{~km}$ of most areas. \\
\hline $\begin{array}{l}\text { Transmission/interconnection } \\
\text { capacity and grid stability }\end{array}$ & 5 & $\begin{array}{l}\text { Ample transmission line and substation capacity for } 20-\text { to } \\
30-\mathrm{MW} \text { wind farm. Many large hydro plants are in this region. } \\
\text { Grid more stable than many other regions. }\end{array}$ \\
\hline Terrain & 2 & Terrain is moderately complex. \\
\hline Accessibility & 1 & $\begin{array}{l}\text { Regional roads are poor. Several sharp corners and narrow } \\
\text { culverts exist on the best roads. Roads may not allow the } \\
\text { transportation of turbines larger than } 500 \mathrm{~kW} \text {. }\end{array}$ \\
\hline $\begin{array}{l}\text { Terrain orientation to prevailing } \\
\text { wind }\end{array}$ & 3 & $\begin{array}{l}\text { Good exposure to southeast monsoon winds, but northeast } \\
\text { monsoon winds do not reach this altitude. }\end{array}$ \\
\hline $\begin{array}{l}\text { Neighbor or community } \\
\text { concerns and social } \\
\text { acceptability }\end{array}$ & 5 & $\begin{array}{l}\text { Local opposition not expected. Good complementary use of } \\
\text { cattle farms. }\end{array}$ \\
\hline Land costs & 5 & Low-cost 99-year leases available from government \\
\hline Vegetation over 10 meters & 5 & Vegetation typically low-level ( $\sim 5 \mathrm{~m})$ scrub. \\
\hline Soil conditions & 4 & Mostly soil with some rocks. \\
\hline $\begin{array}{l}\text { Site environment issues } \\
\text { (corrosion, humidity) }\end{array}$ & 3 & Less corrosive than coastal sites. \\
\hline $\begin{array}{l}\text { Cultural or environmental } \\
\text { concerns }\end{array}$ & 5 & $\begin{array}{l}\text { Issues not expected. Good complementary use of cattle } \\
\text { farms. }\end{array}$ \\
\hline Aviation and telecomm conflicts & 5 & No apparent conflicts. \\
\hline
\end{tabular}




\section{Conclusions and Recommendations for Near-term Wind Power Development}

Sri Lanka has considerable available land with wind resource potential sufficient for development; however, the near-term potential wind power capacity expansion is limited by the electricity transmission infrastructure. CEB estimates the grid can not accommodate additional wind capacity more than $7 \%$ of the peak load, or approximately $100 \mathrm{MW}$. In addition, CEB estimates that installing more than $20 \mathrm{MW}$ of wind capacity in any given region may impact local grid stability. Grid-impact studies should be conducted to identify the major technical issues that limit the grid's capacity for additional wind generation on a regional and system-wide level.

Sri Lanka's $7 \%$ to $8 \%$ annual load growth combined with pressure to decrease electricity tariffs has motivated $\mathrm{CEB}$ and the government to pursue additional and more cost-effective generation technology. This includes fuel-oil and diesel-fired thermal power generation expansion in the near term and large coal-fired thermal generation expansion in the next decade [5].

The current avoided cost for electricity generation in Sri Lanka is approximately $\$ 0.06 / \mathrm{kWh}$. These costs are expensive compared to other countries in the region due to the reliance on imported equipment and fuel along with unfavorable exchange rates. The avoided cost for electricity generation is expected to remain high for at least the next decade when a significant portion of the country's generation capacity is planned to be shifted to coal-fired generation.

Given the current economic climate and infrastructure status in Sri Lanka, there are several locations that show near-term potential for cost-effective utility-scale wind power development. The most promising sites identified, in order of potential feasibility, are the Kalpitiya Peninsula, the National Livestock Board cattle farm near Ambewela and the southeast coastal areas from Hambantota to Buthawa. Several other locations such as Mannar Island and the Jaffna District have favorable wind resource potential; however, the infrastructure and other issues pose significant barriers to near-term development. Table 6-1 summarizes the results of the site evaluation analyses for these sites. 
Table 6-1. Cumulative Site Evaluation Scores

\begin{tabular}{|l|c|c|c|c|c|}
\hline \multicolumn{1}{|c|}{ Criteria } & $\begin{array}{c}\text { Southeast } \\
\text { Coast }\end{array}$ & $\begin{array}{c}\text { Kalpitiya } \\
\text { Peninsula }\end{array}$ & $\begin{array}{c}\text { Mannar } \\
\text { Island }\end{array}$ & Jaffna & $\begin{array}{c}\text { Ambewela } \\
\text { Cattle Farm }\end{array}$ \\
\hline $\begin{array}{l}\text { Wind resource density based on } \\
\text { NREL map }\end{array}$ & 2 & 3 & 3 & 3 & 3 \\
\hline \multicolumn{1}{|c|}{ Weighted Score (multiplier = 5) } & $\mathbf{1 0}$ & $\mathbf{1 5}$ & $\mathbf{1 5}$ & $\mathbf{1 5}$ & $\mathbf{1 5}$ \\
\hline Proximity to transmission lines & 4 & 4 & 1 & 1 & 4 \\
\hline $\begin{array}{l}\text { Upgrades required to existing } \\
\text { transmission lines or substations }\end{array}$ & 3 & 1 & 1 & 1 & 5 \\
\hline Terrain & 5 & 5 & 5 & 5 & 2 \\
\hline Accessibility & 4 & 4 & 1 & 1 & 1 \\
\hline $\begin{array}{l}\text { Terrain orientation to prevailing } \\
\text { wind }\end{array}$ & 3 & 4 & 5 & 5 & 3 \\
\hline Neighbor or community concerns & 5 & 3 & 1 & 1 & 5 \\
\hline Land costs & 5 & 5 & 5 & 5 & 5 \\
\hline Vegetation over 10 m & 5 & 5 & 5 & 5 & 5 \\
\hline Soil conditions & 5 & 5 & 5 & 5 & 4 \\
\hline $\begin{array}{l}\text { Site environment issues } \\
\text { (corrosion, humidity) }\end{array}$ & 2 & 2 & 2 & 2 & 3 \\
\hline Cultural or environment concerns & 3 & 5 & 5 & 5 & 5 \\
\hline Aviation and telecomm conflicts & 5 & 5 & 5 & 5 & 5 \\
\hline \multicolumn{1}{|c|}{ Site Related Subtotal } & $\mathbf{4 9}$ & $\mathbf{4 8}$ & $\mathbf{4 1}$ & $\mathbf{4 1}$ & $\mathbf{4 7}$ \\
\hline TOTAL SCORE & $\mathbf{5 9}$ & $\mathbf{6 3}$ & $\mathbf{5 6}$ & $\mathbf{5 6}$ & $\mathbf{6 2}$ \\
\hline
\end{tabular}

Progress on electrifying rural communities in Sri Lanka is being made primarily through grid extension. Most non-electrified communities are relatively close to the existing grid and thus grid extension has proven less expensive than installing remote off-grid systems for electrification. CEB currently has no plans to pursue the installation of these systems.

\subsection{Kalpitiya Peninsula}

As shown in Table 6-1, the Kalpitiya Peninsula has the most potentially feasible site investigated for utility-scale wind power project development with a total site evaluation score of 63 . This score is higher than all the other sites analyzed even though it reflects the lack of interconnection capacity for additional wind generation in this region. Most other criteria investigated showed the peninsula to be more feasible for development than all other sites analyzed.

A 20-MW wind power project is planed for installation and commissioning on the peninsula in 2004. Once this project is installed, the capacity of the local substation for additional generation will be reached. More wind generation can only be installed in this region if an additional substation is installed and analysis concludes that grid stability in the region will not be affected by more than $20 \mathrm{MW}$ of wind capacity on the peninsula.

Since the Kalpitiya Pensinsula is the most promising site for wind power project development in Sri Lanka, in spite of the interconnection capacity limitations, efforts should be made to investigate the feasibility of installing additional substation capacity and to analyze the impact to grid stability if additional wind power generation is installed beyond the proposed 20-MW project. To support current and future wind power development on the peninsula, wind resource 
monitoring stations should be installed with anemometers at or above $70-\mathrm{m}$ height as well as several lower elevations. This will provide long-term reference data up to elevations consistent with current megawatt-class wind turbine hub heights.

\subsection{Ambewela Cattle Farm}

Analysis results presented in Section 5 list the Central Plains near Ambewela and specifically the National Livestock Board cattle farm area as the second most potentially feasible site investigated for utility-scale wind power project development with a total site evaluation score of 62. The greatest attribute of this site is the Class 5 wind resource. Although the average wind speeds are expected to be higher at this site than on the Kalpitiya Peninsula, the average air density is lower which results in a similar overall wind resource potential.

During the southwest monsoon season, the winds on the cattle farm are very strong. It is expected that the winds for a significant period of the time during the windy season will be at levels above the rated wind speed for most turbines, resulting in a lower annual energy capture than may be expected from simply reviewing the mean wind speed. This phenomenon was not accounted for in the NREL maps since the analysis to produce the maps assumed a Weibull distribution $\mathrm{k}$ value of 2.0 for the whole country. However it is expected that the wind resource potential on the cattle farm site is Class 5 or better.

The installation costs for utility-scale wind power equipment in the Ambewela area are expected to be more expensive than most other regions in the country. As was explained in Section 5.5, the roads in the Central Province are very narrow with several sharp curves. Site development will also be more expensive than the flatter coastal areas.

While the wind resource on the National Livestock Board cattle farm is quite vigorous, the high expected installation costs, comparatively lower air density and sub-optimal annual wind speed frequency distribution raise uncertainties about the potential feasibility of utility-scale wind power project development in the Ambewela area. Conversely, the proximity to transmission lines and relative grid stability in this region, due to the nearness of large hydro schemes, bolsters the potential feasibility of wind development.

Detailed studies on transportation costs to characterize the road upgrade costs vs. installed turbine size relationship should be conducted. Additional system stability studies to determine the maximum wind capacity potential in this region should also be carried out. To support current and future wind power development in this region, wind resource monitoring stations should be installed with anemometers at or above $70 \mathrm{~m}$ height as well as several lower elevations. This will provide long-term reference data up to elevations consistent with current megawatt-class wind turbine hub heights.

\subsection{Southeast Coast}

The wind resource potential of the southeast coast from Hambantota to Buthawa is listed as Class 4 by the NREL maps. Although the site development costs are expected to be comparable to Kalpitiya and less than the Ambewela cattle farm, the overall potential feasibility of utilityscale wind project development is estimated to be less than these two sites due to the less 
energetic wind resource. The overall site evaluation score presented in Section 5 for the southeast coast region is 59 .

Much of the coastal areas, where the wind resource is best in this region, are national park and reserve land, which are excluded from development. The remaining land may undergo more strenuous environmental review of development plans than in other parts of the country due to the proximity of national park and range land. Since the winds in this region are generally parallel to the coast, turbine rows would need to be installed perpendicular to the coast but less than one or two kilometers inland where the winds are attenuated considerably. This arrangement will require a comparatively larger amount of coastal land than if the wind direction were offshore. For these reasons, it may be difficult to site wind power projects of $20 \mathrm{MW}$ or larger capacity on the southeast coast.

The southeast coast may be a candidate for wind power project development if the Kalpitiya Peninsula and Central Plains regions are developed to capacity or otherwise precluded from development. If that is the case, rigorous wind resource and siting studies should be conducted to determine a site on the southeast coast that does not have competing uses and has wind resource potential to support cost effective wind power development.

\subsection{Estimated Cost of Energy}

To illustrate the potential economic feasibility, GEC calculated the levelized cost of energy (COE) for a 20-MW wind project at each of the three top-scoring sites, the southeast coast, Kalpitiya Peninsula, and Ambewela. The COE is a common cost evaluation tool for comparing alternative technologies or sites. The COE formula used in the following analysis is based on the Electric Power Research Institute's (EPRI) Technical Assessment Guide (TAG). The simplified EPRI TAG formula for estimating the COE is defined below.

$\mathrm{COE}=\underline{(\mathrm{ICC} x \mathrm{FCR})+\text { Annual O\&M}}$

AEP

Where: $\quad$ ICC $=$ initial capital cost

$\mathrm{FCR}=$ fixed charge rate

$\mathrm{AEP}=$ annual energy production

The estimated initial capital cost accounts for all costs associated with developing a project including turbine equipment, balance-of-station, and project development costs. The estimated capital cost considers actual current equipment costs for a wind turbine in the $600-\mathrm{kW}$ size range and reasonable balance-of-system costs for a $20-\mathrm{MW}$ project. The variation in capital costs between the three sites accounts for anticipated differences in overland transportation of the equipment from the port to the project site and for the cost of civil, electrical, and turbine erection costs associated with the specific terrain and site accessibility. The estimated capital costs for the three sites range from $\$ 1,195$ to $\$ 1,325$ per $\mathrm{kW}$. While large commercial wind projects using 1-MW and larger turbines in the United States are being installed for $\$ 900$ $1,000 / \mathrm{kW}$, the cost for these smaller turbines and a relatively small project is expected to be higher. 
The FCR is the expected carrying cost of the debt and equity. For this analysis, the FCR is assumed to be $9.5 \%$ based on anticipated financing terms. Low-cost debt financing is expected to be available through a development bank with a relatively high debt-to-equity ratio. Based on recent experience with development bank financing, GEC assumed a debt-equity ratio of 70/30 with debt interest at 5\% and a required equity return of $20 \%$.

Annual operating and maintenance (O\&M) costs are based on $\$ 0.015 / \mathrm{kWh}$ of energy production. This level of O\&M expense is higher than that of typical U.S. commercial projects. The higher costs are assumed in this analysis to account for limited wind capacity expected to be in Sri Lanka in the near-term. Because of the large number of wind projects in nearby India, the actual O\&M costs may be lower than estimated.

Based on the measured wind speed, a representative turbine power curve, and reasonable energy losses, estimated capacity factors ranged from $26 \%$ to $34 \%$. The basic components of the COE calculation and the resulting COE for the three sites are summarized in Table 6-2. Although not a direct component of the COE, the estimated annual wind speeds are also included in Table 6-2.

As shown in Table 6-2, a wind project on the Kalpitiya Peninsula is expected to result in the lowest COE of the three sites. A project on the southeast coast may not be economical if the basis for determining economic viability is the avoided cost of approximately $\$ 0.06$ per $\mathrm{kWh}$.

Table 6-2. Estimated Cost of Energy

\begin{tabular}{|l|c|c|c|}
\hline \multicolumn{1}{|c|}{ Criteria } & $\begin{array}{c}\text { Southeast } \\
\text { Coast }\end{array}$ & $\begin{array}{c}\text { Kalpitiya } \\
\text { Peninsula }\end{array}$ & $\begin{array}{c}\text { Ambewela } \\
\text { Cattle Farm }\end{array}$ \\
\hline $\begin{array}{l}\text { Capital Cost } \\
\text { (per kW) }\end{array}$ & $\$ 1,195$ & $\$ 1,220$ & $\$ 1,325$ \\
\hline $\begin{array}{l}\text { Fixed Charge } \\
\text { Rate }\end{array}$ & $9.5 \%$ & $9.5 \%$ & $9.5 \%$ \\
\hline $\begin{array}{l}50-\mathrm{m} \text { Wind } \\
\text { Speed (m/s) }\end{array}$ & 7.0 & 7.6 & 7.9 \\
\hline Capacity Factor & $26 \%$ & $34 \%$ & $32 \%$ \\
\hline O\& M per kWh & $\$ 0.015$ & $\$ 0.015$ & $\$ 0.015$ \\
\hline $\begin{array}{l}\text { COE Estimate } \\
\text { (\$/kWh) }\end{array}$ & $\$ 0.065$ & $\$ 0.054$ & $\$ 0.060$ \\
\hline
\end{tabular}




\section{References}

1. Sri Lanka Wind Resource Atlas, NREL/TP-500-34518, National Renewable Energy Laboratory, Golden, Colorado, 2003.

2. Feasibility Study for a 3 MW Pilot Wind Farm in Sri Lanka, RLA Consulting, Inc., Bothell, Washington, March 1997.

3. Fernando, K.S., Kariyawasam, P. L. G., Alwis, A.M.A., Wind Energy Resource Assessment - Puttalam and Central Regions of Sri Lanka, Ceylon Electricity Board, Colombo, Sri Lanka, April 2002.

4. Long Term Transmission Development Studies 2002 - 2011, Ceylon Electricity Board, Colombo, Sri Lanka, August 2002.

5. Long Term Generation Expansion Plan 2002 - 2016, Ceylon Electricity Board, Colombo, Sri Lanka, December 2001.

6. Request for Proposals for the Establishment of Wind Power Plant on Build, Own and Operate Basis, Government of Sri Lanka/Ministry of Power and Energy/Ceylon Electricity Board, Colombo, Sri Lanka, December 2002. 


\section{REPORT DOCUMENTATION PAGE}

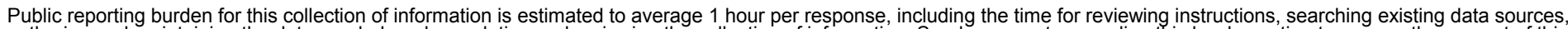

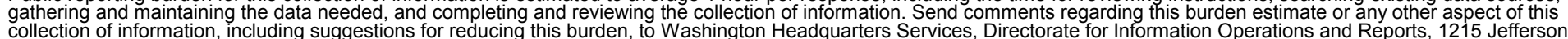
Davis Highway, Suite 1204, Arlington, VA 22202-4302, and to the Office of Management and Budget, Paperwork Reduction Project (0704-0188), Washington, DC 20503.
1. AGENCY USE ONLY (Leave blank)
2. REPORT DATE
August 2003
3. REPORT TYPE AND DATES COVERED
Subcontractor Report

4. TITLE AND SUBTITLE

Sri Lanka Wind Farm Analysis and Site Selection Assistance

5. FUNDING NUMBERS

WF7C. 2000

ACX-3-33455-01

6. $\operatorname{AUTHOR}(\mathrm{S})$

M. Young and R. Vilhauer

7. PERFORMING ORGANIZATION NAME(S) AND ADDRESS(ES)

Global Energy Concepts, LLC

8. PERFORMING ORGANIZATION REPORT NUMBER

5729 Lakeview Drive NE, Suite 100

Kirkland, Washington 98033-7340

9. SPONSORING/MONITORING AGENCY NAME(S) AND ADDRESS(ES)

National Renewable Energy Laboratory

1617 Cole Blvd.

Golden, CO 80401-3393

10. SPONSORING/MONITORING AGENCY REPORT NUMBER

NREL/SR-710-34646

11. SUPPLEMENTARY NOTES

NREL Technical Monitor: I. Baring-Gould

12a. DISTRIBUTION/AVAILABILITY STATEMENT

National Technical Information Service

U.S. Department of Commerce

5285 Port Royal Road

Springfield, VA 22161

13. ABSTRACT (Maximum 200 words)

The United States Department of Energy (DOE), through the National Renewable Energy Laboratory (NREL), has been working in partnership with the U.S. Agency for International Development (USAID) in an on-going process to quantify the Sri Lanka wind energy potential and foster wind energy development. Work to date includes completion of the NREL wind atlas for Sri Lanka. In addition, the Ceylon Electricity Board (CEB) has conducted a wind resource assessment of several areas of the country and has successfully completed and is currently operating a 3-MW pilot wind project. A review of the work completed to date indicates that additional activities are necessary to provide Sri Lanka with the tools necessary to identify the best wind energy development opportunities. In addition, there is a need to identify key policy, regulatory, business and infrastructure issues that affect wind energy development and to recommend steps to encourage and support wind power development and investment.

14. SUBJECT TERMS

Sri Lanka; wind energy; wind energy potential; wind energy development; wind atlas; wind power development

15. NUMBER OF PAGES

17. SECURITY CLASSIFICATION OF REPORT Unclassified
18. SECURITY CLASSIFICATION OF THIS PAGE Unclassified
19. SECURITY CLASSIFICATION OF ABSTRACT Unclassified
16. PRICE CODE

20. LIMITATION OF ABSTRACT

UL

NSN 7540-01-280-5500

Standard Form 298 (Rev. 2-89) Prescribed by ANSI Std. Z39-18 